\title{
The hydrogeochemistry of methane: evidence from English groundwaters
}

W G Darling ${ }^{*}$ and D C Gooddy

British Geological Survey, Wallingford, Oxfordshire, OX10 8BB, UK

*Corresponding author: phone +44 (0) 1491692326

fax $\quad+44(0) 1491692345$

e-mail wgd@bgs.ac.uk

W G Darling

Maclean Building

British Geological Survey

Wallingford

Oxfordshire, OX10 8BB, UK

\begin{abstract}
The presence of methane $\left(\mathrm{CH}_{4}\right)$ in groundwater is usually only noticed when it rises to high concentrations; to date rather little is known about its production or natural 'baseline' conditions. Evidence from a range of non-polluted groundwater environments in England, including water-supply aquifers, aquicludes and thermal waters, reveals that $\mathrm{CH}_{4}$ is almost always detectable, even in aerobic conditions. Measurements of potable waters from Cretaceous, Jurassic and Triassic carbonate and sandstone aquifers reveal $\mathrm{CH}_{4}$ concentrations of up to $500 \mu \mathrm{g} / \mathrm{l}$, but a mean value of $<10 \mu \mathrm{g} / \mathrm{l}$. However, aquiclude and thermal waters from the Carboniferous and Triassic typically contain in excess of $1500 \mu \mathrm{g} / \mathrm{l}$. Such high concentrations have so far only been found at redox (Eh) potentials below $0 \mathrm{mV}$, but in general $\mathrm{CH}_{4}$ concentration and Eh value are poorly correlated. This suggests a lack of thermodynamic equilibrium, which is confirmed by comparing pe values calculated from the redox couple $\mathrm{C}(-4) / \mathrm{C}(+4)$ with those derived from Eh. Genesis of $\mathrm{CH}_{4}$ appears to occur on two timescales: a rapid if low rate of production from labile carbon in anaerobic microsites in the soil, and a much longer, millennium scale of production from more refractory carbon. Methane is rarely measured in groundwater; there is no single ionic determinand which acts universally as a proxy, but a combination of high $\mathrm{HCO}_{3}$ and low $\mathrm{SO}_{4}$ concentrations, or the reverse, is an indication that high amounts of $\mathrm{CH}_{4}$ may be present.
\end{abstract}

Keywords: Methane, aquifers, redox, carbon isotopes, Chalk, limestone, sandstone 


\section{INTRODUCTION}

There are three reasons to study the occurrence of methane $\left(\mathrm{CH}_{4}\right)$ in groundwaters: (i) as part of the contribution to the atmospheric budget ('emissions'), (ii) as a potential explosive hazard ('safety'), and (iii) more fundamentally its production characteristics. For the UK, emissions and safety have been addressed by Gooddy and Darling (2005). The present paper complements that approach by considering the third factor via a detailed study of hydrogeochemistry of a range of groundwater types.

The presence of $\mathrm{CH}_{4}$ in groundwater is usually only noticed when it rises to problem concentrations. These have on occasion caused explosive incidents in Europe and North America (e.g. Altnöder and Hutter, 1981; Buswell and Larson, 1937; Kelly et al, 1985). In some of these cases it is clear that $\mathrm{CH}_{4}$ has leaked into the groundwater from adjacent strata, whereas in others the origin is less evident. In the UK rather little appears to be known about the occurrence of $\mathrm{CH}_{4}$ in groundwater beyond a few high-profile incidents (Hooker and Bannon, 1993; HSE, 2000). The present paper is not concerned with such incidents but instead focuses on 'baseline' conditions by looking at regional distributions of dissolved $\mathrm{CH}_{4}$ and the differences between aquifer types. A knowledge of typical background $\mathrm{CH}_{4}$ concentrations will inter alia provide a more secure context for the interpretation of future methane survey or incident data, particularly for NW Europe where similar aquifer types are exploited.

\section{BACKGROUND}

\subsection{Occurrence of methane}

Apart from some rather specific instances, such as the supposed 'abiogenic' $\mathrm{CH}_{4}$ in ophiolite complexes or crystalline shield rocks (Neal and Stanger, 1982; Sherwood et al, 1988), most $\mathrm{CH}_{4}$ finding its way into groundwater has been produced from organic matter, either via thermal ('thermogenic') or bacterial ('biogenic') mediation (Schoell, 1988). Thermogenic $\mathrm{CH}_{4}$ is associated with many petroleum reservoirs or natural gas fields and also with their storage and distribution systems (Barker and Fritz, 1981; Kelly et al, 1985). Biogenic $\mathrm{CH}_{4}$ has been documented in anaerobic groundwater environments, including peat bogs, lignite deposits, and glacial, lacustrine and eolian sediment (Barker and Fritz, 1981; Coleman et al., 1988; Grossman et al., 1989).

The origin of $\mathrm{CH}_{4}$ in groundwater systems can be deduced using several lines of evidence. Simple hydrochemical methods in the field or laboratory can often be used to determine 
origins (Games and Hayes, 1976; Jakobsen and Postma, 1999). Where these are more cryptic, study of the gas phase itself may be necessary. For example, the presence of $\mathrm{C}_{2+}$ hydrocarbons in significant proportion indicates a thermogenic origin for the gas, while microbial $\mathrm{CH}_{4}$ rarely contains detectable hydrocarbons higher than ethane, and typically has very high $\mathrm{C}_{1} / \mathrm{C}_{2}$ ratios (Barker and Fritz, 1981). Carbon stable isotope ratios can be diagnostic of 'light' biogenic or 'heavy' thermogenic or abiogenic origins (Schoell, 1988).

Traditionally $\mathrm{CH}_{4}$ has been predicted to occur in groundwaters only when conditions are sufficiently reducing (e.g. Edmunds et al, 1984), otherwise oxidation should occur (Smith et al, 1991). In effect this implies a necessity for confined aquifer conditions where dissolved oxygen (DO) concentrations have been reduced to significantly less than the normal detection limit of $0.1 \mathrm{mg} / \mathrm{l}$. In practice, the present study shows that groundwater $\mathrm{CH}_{4}$ is almost ubiquitously present above detection limit whether the aquifer is confined or not.

This wide distribution of $\mathrm{CH}_{4}$ in English aquifers suggests an origin predominantly via bacterial activity rather than from thermogenic ('natural gas') or abiogenic ('deep methane') quasi-point sources, for which there is generally little evidence (though instances of gas seepage in areas not covered in this study are recorded by Selley, 1992). Bacterial (or biogenic) $\mathrm{CH}_{4}$ can be produced via two routes: decarboxylation (fermentation) of acetate, or reduction of $\mathrm{CO}_{2}$ (Whiticar et al, 1986). The first of these produces both $\mathrm{CH}_{4}$ and $\mathrm{CO}_{2}$, the second $\mathrm{CH}_{4}$ only. The difference between these processes has implications for $\delta^{13} \mathrm{C}$ distributions (e.g. Clark and Fritz, 1997), but most baseline $\mathrm{CH}_{4}$ concentrations are too low (i) to allow the determination of $\delta^{13} \mathrm{C}-\mathrm{CH}_{4}$ and (ii) to have a significant effect on DIC (dissolved inorganic carbon) in concentration or isotopic terms.

In order to produce $\mathrm{CH}_{4}$, methanogenic bacteria require an absence of oxygen. Particularly where aquifers are unconfined, there is likely to be $\mathrm{O}_{2}$ available in both the saturated and unsaturated zones. However, in both zones it is possible for anaerobic 'hot spots' to develop around organic matter (Murphy et al, 1992), when the uptake of $\mathrm{O}_{2}$ exceeds the rate of its diffusivity (Vinten et al, 1996). This might permit production of $\mathrm{CH}_{4}$ at a low rate.

Both acetate fermentation and $\mathrm{CO}_{2}$ reduction processes may proceed simultaneously (Conrad 1999) but neither is a very thermodynamically favourable reaction (Chapelle 1993). Generally, acetate fermentation is the primary pathway for methane formation in lake sediments (Kuivila et al, 1989), whereas $\mathrm{CO}_{2}$ reduction tends to dominate in marine sediments (Hoehler et al, 1994). The reason for this is that sulphate is abundant in seawater 
and its reduction in marine sediments is an important precursor for methanogenesis and is responsible for most acetate metabolism (Whiticar 1999). Reduction of $\mathrm{CO}_{2}$ can only occur where conditions are sufficiently reducing to produce $\mathrm{H}_{2}$, a situation typical of environments such as landfills or peat bogs (Lansdown et al, 1992). For most groundwaters, therefore, acetate fermentation appears to be a more likely route to $\mathrm{CH}_{4}$ production (e.g. Chapelle 1993), although $\mathrm{CO}_{2}$ reduction has been identified as the dominant process in certain cases (e.g. Barker and Fritz 1981; Aravena et al, 1995).

Data are compared from six groundwater environments: the Chalk (Upper Cretaceous), the Lower Greensand (Lower Cretaceous), the Lincolnshire Limestone (Middle Jurassic), the Sherwood Sandstone (Triassic), Namurian shales (Upper Carboniferous), and thermal waters from the Triassic and Carboniferous.

\subsection{Geochemical indicators}

Any study of $\mathrm{CH}_{4}$ hydrogeochemistry requires consideration of two primary areas: redoxsensitive indicators and carbon cycling.

\subsubsection{Redox indicators}

Methanogenesis represents the last of a series of reactions where electron acceptors such as $\mathrm{O}_{2}, \mathrm{NO}_{3}{ }^{-}, \mathrm{Mn}^{4+}, \mathrm{Fe}^{3+}$ and $\mathrm{SO}_{4}{ }^{2-}$ are used sequentially to oxidise organic matter. This form of oxidation is predominantly via dissimilative metabolism by bacteria that can utilise a range of potential Terminal Electron Acceptor Processes (TEAPs) in the reaction. The range of TEA species is characterised by differences in the energy yield they provide when used in respiration. Owing to the problems often associated with interpretation of Eh measurements using a platinum electrode, redox environments are often classified in terms of the appearance of species such as $\mathrm{Mn}^{2+}, \mathrm{Fe}^{2+}, \mathrm{H}_{2} \mathrm{~S}$ and $\mathrm{CH}_{4}$ or the disappearance of $\mathrm{O}_{2}, \mathrm{NO}_{3}{ }^{-}$and $\mathrm{SO}_{4}{ }^{2-}$. Lovley and Goodwin (1988) have measured $\mathrm{H}_{2}$ directly and proposed specific $\mathrm{H}_{2}$ concentration ranges for different TEAPs. However, both Jakobsen and Postma (1999) and Hansen et al (2001) found the $\mathrm{H}_{2}$ concentrations were not indicative of the TEAP according to the ranges defined by Lovely and Goodwin (1988). This is because $\mathrm{H}_{2}$ reaction is strongly temperature dependent and thermodynamically controlled (Jakobsen et al, 1998) in addition to depending on the concentration of other TEAs (Hoehler et al, 1998)

Environments can be considered as either oxic or anoxic, with a DO cut-off of about $0.05 \mathrm{mg} / \mathrm{l}$, i.e. slightly below the typical detection limit of $0.1 \mathrm{mg} / \mathrm{l}$. Anoxic environments are further subdivided into post-oxic; which is dominated by the reduction of nitrate, manganese oxides and/or iron oxides; sulphidic, where sulphate reduction occurs; and finally the 
methanic (or methanogenic) zone (Berner, 1981). Not all of these zones are invariably present and a groundwater may completely by-pass one of these states depending on the composition of the aquifer and the nature of the organic material. For example, Gooddy et al (2002) found a nitrate reducing zone, a sulphate reducing zone and a methanogenic zone resulting from the infiltration of cattle slurry beneath farm waste stores sited on Chalk in southern England. No manganese or iron reduction was found since these are not present at significant concentrations in the Chalk matrix, whereas nitrogen and sulphur are component parts of the cattle slurry. By comparison, Lawrence et al (2000) found a complete redox sequence in an iron and manganese rich alluvial aquifer receiving unsewered urban wastewaters. Neither of these cases represents baseline conditions, but they illustrate well the importance of groundwater environment to redox processes.

In this paper Eh, dissolved $\mathrm{O}_{2}, \mathrm{Fe}$ and $\mathrm{SO}_{4}$ are used as a representative spread of redoxsensitive indicators (see Results).

\subsubsection{Carbon cycling}

In many groundwaters the majority of dissolved carbon is inorganic ('DIC'). This will be distributed between carbonate $\left(\mathrm{CO}_{3}{ }^{2-}\right)$, bicarbonate $\left(\mathrm{HCO}_{3}{ }^{-}\right)$and dissolved $\mathrm{CO}_{2}\left(\mathrm{H}_{2} \mathrm{CO}_{3}\right)$, the proportions depending on $\mathrm{pH}$ and $\mathrm{pCO}_{2}$ (e.g. Clark and Fritz, 1997). Most potable groundwater is of near-neutral $\mathrm{pH}$ where $\mathrm{HCO}_{3}{ }^{-}$is dominant, so analyses of DIC are typically reported as $\mathrm{HCO}_{3}{ }^{-}$. Determination of DIC is however based on titration of alkalinity; while the alkalinity of most groundwaters will be overwhelmingly due to DIC, there are instances (for example in brines) where acetate or even sulphide may be an important component.

Groundwater acquires its initial DIC content via the reaction of soil $\mathrm{CO}_{2}$ with rock carbonate. At the same time it acquires a small component of soil organic carbon ('DOC'), conventionally divided into heavy molecular weight ('HMW') and light molecular weight ('LMW') fractions (Murphy et al, 1989). The dissolved organic carbon in groundwater is a diverse mixture of organic compounds which can come from various sources. Both initial DIC and DOC contents may be raised by further interaction with aquifer materials, but DOC tends to remain some two orders of magnitude below DIC in concentration weight-forweight. Its significance in the mass balance of the overall C-cycle is therefore minimal, though it may be important for other reasons to be discussed below. This also applies to the other main organic component of groundwater, $\mathrm{CH}_{4}$ itself, which may be produced from organic or inorganic sources as outlined above. 
Stable isotope ratios play a key role in understanding the fate of carbon in groundwater. The 1:1 reaction of dissolved soil $\mathrm{CO}_{2}$ with soil or rock carbonate at neutral $\mathrm{pH}$ results in a water with a $\delta^{13} \mathrm{C}_{\mathrm{DIC}}$ composition approximately halfway between the two, which may be depleted by further equilibration with $\mathrm{CO}_{2}$ or enriched by subsequent water-rock interaction (e.g. Clark and Fritz, 1997). The bacterially-mediated transformation of DIC into $\mathrm{CH}_{4}$ is characterised by the bacteria's preference for breaking ${ }^{12} \mathrm{C}-\mathrm{H}$ bonds, resulting in the typically depleted $\delta^{13} \mathrm{C}$ values for $\mathrm{CH}_{4}$. Subsequent oxidation or further interactions between $\mathrm{C}$ phases tends to alter $\delta^{13} \mathrm{C}$ values along well-characterised reaction paths (Clark and Fritz, ibid), giving an indication of C-system evolution.

The role of radiocarbon $\left({ }^{14} \mathrm{C}\right)$ in this study has less to do with carbon cycling processes (though this is an important consideration in its interpretation) than with giving an indication of water residence time. Nevertheless it is appropriate to view it as a 'carbon parameter' (see Results).

\subsection{Groundwater environments}

Three different groundwater settings are considered: (i) sedimentary aquifers with a range of redox conditions; (ii) thermal waters; and (iii) the waters associated with some aquicludes.

Since much groundwater abstraction in England is for public water supply, most data have been obtained from the major aquifers. In descending stratigraphical order these are the Chalk, Lower Greensand, Lincolnshire Limestone, and Sherwood Sandstone. Depending on the down-gradient location, the quality of water in these aquifers can be poor and this is where higher $\mathrm{CH}_{4}$ concentrations tend to be found.

Three examples of thermal waters are considered: two actively circulating (Carboniferous Limestone of Buxton and Bath), the third apparently immobile (Sherwood Sandstone of the Southampton area).

By far the highest natural dissolved $\mathrm{CH}_{4}$ concentrations are associated with formations typically regarded as aquicludes. Most notably these high- $\mathrm{CH}_{4}$ waters have been revealed as a result of tunnelling in Namurian rocks in northern England.

\section{SAMPLING AND ANALYSIS}

Samples for $\mathrm{CH}_{4}$ analysis were collected by a variety of methods, all of which relied on the partitioning or stripping of dissolved gas from measured amounts of water into headspaces of known volume (TWA, 1986). Gas extracted from these headspaces was analysed for $\mathrm{CH}_{4}$ 
(plus $\mathrm{C}_{2} \mathrm{H}_{6}$ and $\mathrm{C}_{3} \mathrm{H}_{8}$ where appropriate) by gas chromatography using a porous polymer column and a flame ionisation detector. The detection limit of this method is better than 1 part per million by volume (ppmv), corresponding to a dissolved concentration at $10^{\circ} \mathrm{C}$ of approximately $0.05 \mu \mathrm{g} / \mathrm{l}$.

Where dissolved concentrations were sufficiently high, isotopic measurements of $\delta^{13} \mathrm{C}-\mathrm{CH}_{4}$ were made by oxidation of extracted gas over $\mathrm{CuO}$ at $850^{\circ} \mathrm{C}$, followed by cryogenic separation prior to mass spectrometric analysis. Precision of these measurements was $\pm 0.5 \%$.

In one part of the Chalk aquifer, measurements of radiocarbon activity in dissolved organic carbon (DOC) were made to compare with previous conventional inorganic (DIC) results. Samples for ${ }^{14} \mathrm{C}_{\mathrm{DOC}}$ analysis were prepared by extraction of the HMW compounds (humic and fulvic acids) from approximately 50 litres of groundwater onto a DEAE-cellulose resin (Miles et al, 1983). The HMW compounds were eluted from the resin using 0.5 $\mathrm{M} \mathrm{NaOH}$. The eluant was acidified to $\mathrm{pH} 1$ with $\mathrm{HCl}$ to precipitate the humic acid fraction while the fulvic acid fraction remained in the eluant. Analysis of the fulvic acid fraction was carried out by AMS (Accelerator Mass Spectrometry) via the NERC Radiocarbon Laboratory at East Kilbride, Scotland, with an average precision of \pm 2.8 pmc (percent modern carbon).

Supporting hydrochemical and isotopic data are either original or derived from reports and publications as credited in the tables of results; all were obtained by standard methods.

\section{RESULTS}

\subsection{The Chalk aquifer of the wider London Basin}

The Chalk of southern Britain is a generally rather pure fine-grained limestone which although possessing a high primary porosity is considered to act mainly as a fractured aquifer because of the considerable amount of fissuring and the very tight pore throats in the matrix (Price, 1987). This combination can result in unusual hydrogeochemical effects in the sense that the fractures promote rapid mixing while the porosity encourages slow diffusional exchange (Barker and Foster 1981).

The Chalk of the London Basin outcrops in the Chilterns and North Downs before becoming confined down-dip by a covering of younger Palaeogene sediments consisting mainly of impermeable London Clay (Fig 1). Four methane transects were measured across parts of the basin, moving from the unconfined to confined zones: NW-SE in the area south of Reading, Berkshire; W-E, from Maidenhead into Central London; S-N, from Croydon into the Central 
London; and SW-NE in the Medway area northeast of Maidstone, Kent. A number of confined sites running $\mathrm{N}-\mathrm{S}$ down the Lee Valley were also included. Some of the sites in south and east London measured for $\mathrm{CH}_{4}$ by the then Thames Water Authority (TWA, 1986) were also investigated. The results are given in Table 1 .

Methane concentrations versus distance from the onset of confinement are plotted for samples from the four transects in Fig 2. This shows that concentrations do not exceed $0.5 \mu \mathrm{g} / \mathrm{l}$ in the unconfined aquifer. Values can remain this low up to $5 \mathrm{~km}$ from the boundary, but typically begin to rise until a plateau is reached at about $10 \mathrm{~km}$ with values usually in the range $0.5-10 \mu \mathrm{g} / 1$, though samples from the Medway Chalk are an order of magnitude higher in concentration.

The relationship between $\mathrm{CH}_{4}$ concentration and redox parameters is poorly defined (Fig 4). Nevertheless, as $\mathrm{CH}_{4}$ rises there is generally a decline in Eh and dissolved $\mathrm{O}_{2}$, and an increase in $\mathrm{Fe}$. There is however little sign of $\mathrm{SO}_{4}$ being much affected by reduction. In fact, as Edmunds et al (1984) pointed out, dissolved $\mathrm{SO}_{4}$ tends to increase with residence time as sulphate minerals slowly dissolve, up to the point where conditions become reducing enough for conversion to sulphide. When sampling Chalk groundwaters beneath London, Smith et al (1976) seldom found evidence of sulphate-reducing bacteria.

There also appears to be a poor relationship between $\mathrm{CH}_{4}$ concentration and inorganic carbon system parameters (Fig 4). While concentrations near to or below detection limit are invariably associated with lower values of $\mathrm{HCO}_{3}$ and $\delta^{13} \mathrm{C}-\mathrm{DIC}$, high concentrations show no trends. The same is largely true for radiocarbon, though the Medway samples show an apparent evolutionary relationship. Also available are some ${ }^{14} \mathrm{C}_{\mathrm{DOC}}$ results, though only for selected sites in the Berkshire Chalk (Table 2). These have a similarly poor correlation with $\mathrm{CH}_{4}$ concentration, with the apparently oldest site (CK45) having the lowest $\mathrm{CH}_{4}$ concentration.

The area of the Lee Valley where Sites CK31-CK36 are situated has been the focus of an investigation into water quality issues relating to pyrite oxidation in the overlying and hydraulically-connected Basal Sands of the Palaeogene (Kinniburgh et al, 1994). The balance of evidence (low $\mathrm{HCO}_{3}$, intermediate $\delta^{13} \mathrm{C}_{\text {DIC }}$ and in one case ${ }^{14} \mathrm{C}$ values) suggests leakage from the Basal Sands mixing with Chalk water, but conditions remain reducing enough for $\mathrm{CH}_{4}$ concentrations to be typical of those found in the centre of the London Basin 


\subsection{The Lower Greensand of southeast England}

The Lower Greensand is typically a glauconitic sandstone with zones of partial cementation which do not however prevent the formation from generally being a good aquifer, albeit subject to complex lateral facies changes (Duff and Smith, 1992). The Lower Greensand is hydraulically isolated from the overlying Chalk by the Gault Clay, which is a highly-effective aquiclude.

The Lower Greensand outcrop basically follows the scarp slope of the Chalk in southeast England with a rather wider outcrop in the Wealden area south of London than that paralleling the Chalk of the Chiltern Hills to the northwest (Fig 4). Owing to a combination of deposition and erosion effects, the Lower Greensand is not uniformly present beneath the Chalk of the London Basin, but is certainly present under the western side of the basin. Where the Lower Greensand is confined it is usually overlain by the Chalk and relatively few boreholes are drilled into the lower aquifer. However for reasons of water quality a number of boreholes do penetrate to the Lower Greensand even in areas of relatively thick overburden, such as around Slough to the west of London.

The Lower Greensand samples were obtained from an approximately NNE-SSW transect across the western London Basin from Cambridgeshire/Bedfordshire to Surrey/Hampshire, although a site in north Kent near Maidstone is also included (Fig 4). Results are reported in Table 3. Methane concentrations for three more unconfined sites in west Kent are reported in TWA (1986).

Waters from both the unconfined and confined Lower Greensand have $\mathrm{CH}_{4}$ concentrations generally an order of magnitude greater than those in the Chalk (Fig 5). It is not clear if or where a plateau in concentration is reached because of the lack of boreholes between 15 and $30 \mathrm{~km}$ from outcrop.

Redox parameters are plotted versus $\mathrm{CH}_{4}$ concentration in Fig 6. (Unlike for the Chalk, it is not necessary to plot this axis on a $\log$ scale because of the relatively small $\mathrm{CH}_{4}$ concentration range.) As with the Chalk, $\mathrm{SO}_{4}$ is poorly correlated with $\mathrm{CH}_{4}$ concentration, but otherwise the contrast between the two aquifers is large. Eh declines sharply to about $+200 \mathrm{mV}$, then more gradually, while there is a steep decline in DO to the detection limit. Fe shows a trend basically similar to Eh, but this is the reverse of what would normally be expected. The reason is probably ready availability of Fe from the ferruginous cementation in the more northerly parts of the aquifer, a factor related to facies changes (Duff and Smith, 1992). 
Bicarbonate and $\delta^{13} \mathrm{C}_{\text {DIC }}$ show tendencies to increase slightly with $\mathrm{CH}_{4}$ concentration (Fig 6). There is a good relationship between ${ }^{14} \mathrm{C}$ and $\mathrm{CH}_{4}$ concentration for nearly all sites below $5 \mu \mathrm{g} / \mathrm{l}$, but this is not related to a particular geographical area and may be coincidental. At higher concentrations the correlation disappears.

\subsection{The Lincolnshire Limestone of eastern England}

The Lincolnshire Limestone is an oolitic formation. As a carbonate aquifer its main permeability is fractured, but it differs from the Chalk in having a much lower porosity. Thus the buffering tendency typical of the Chalk is much less developed in the Lincolnshire Limestone.

The Lincolnshire Limestone outcrops in eastern England (Fig 7). Although time-equivalent Middle Jurassic strata extend to the north and southwest, facies changes render these units less suitable for water supply and they are not heavily developed.

The Lincolnshire Limestone samples were obtained from a variety of locations which, with the exception of one unconfined site, extend from Lincoln along a transect into the down-dip confined portion of the aquifer in the Spalding area (Fig 7). Results (taken largely from Bishop and Lloyd, 1990, 1991) are provided in Table 4.

With the exception of two sites (LL5 and LL6), $\mathrm{CH}_{4}$ concentrations do not appear to rise much above $10 \mu \mathrm{g} / \mathrm{l}$ with the onset of confinement (Fig 8). The very high levels of LL5 and LL6 could be due to due to leakage of gas from an underlying source or, perhaps more likely, the consequence of tapping into a relatively stagnant part of the aquifer. (This is considered in more detail in 4.7 below.)

Figure 11 shows the redox parameters $\mathrm{Eh}$ and $\mathrm{SO}_{4}$ plotted against $\mathrm{CH}_{4}$ concentration (measurements of DO and Fe are generally not available for these sites). As with the Chalk, a log scale is used for $\mathrm{CH}_{4}$ because of the large concentration range. Both Eh and, unusually for this study, $\mathrm{SO}_{4}$ fall as $\mathrm{CH}_{4}$ rises. The decline in $\mathrm{SO}_{4}$ is likely to be the consequence of the low redox potentials (down to $-140 \mathrm{mV}$ ) found in parts of the confined aquifer; Downing et al (1977) found evidence of sulphate-reducing bacteria in Lincolnshire Limestone groundwaters to the south of the area considered here.

As far as the carbon system is concerned, the $\mathrm{HCO}_{3}$ concentration barely changes except for the high- $\mathrm{CH}_{4}$ samples from LL5 and LL6 (Fig 9), which have concentrations over $100 \mathrm{mg} / \mathrm{l}$ higher than any other site. However, $\delta^{13} \mathrm{C}$ and $\mathrm{A}^{14} \mathrm{C}$ decline to near-zero values before $\mathrm{CH}_{4}$ reaches $10 \mu \mathrm{g} / 1$. 


\subsection{The Sherwood Sandstone of the East Midlands}

The Sherwood Sandstone aquifer lies beneath the Lincolnshire Limestone, hydraulically isolated from it by the highly impermeable units of the Lias (Jurassic) and the Mercia Mudstone (Triassic). Because of a regional dip to the east for Mesozoic strata, the outcrop of the Sherwood Sandstone tends to parallel that of the Lincolnshire Limestone.

The Sherwood Sandstone is a well-sorted desert sandstone with good intergranular permeability. As an aquifer it is second only to the Chalk in its use as a groundwater resource. Boreholes abstract from both the unconfined and confined portions of the aquifer. The samples taken during this study (Table 5) were collected from a range of boreholes which, although not on a line of section as such, include representatives from the unconfined and confined portions of the aquifer (Fig 10).

The plot of $\mathrm{CH}_{4}$ concentration against distance from the onset of confinement shows some features not found in the other aquifers (Fig 11). Values in the confined zone are on average very low (though it must be noted that the most down-dip sample is only $8 \mathrm{~km}$ into confinement). More significantly, a very high value was obtained from the unconfined site $\mathrm{SS} 12$. Although this does have low $\mathrm{Eh}$ and $\mathrm{SO}_{4}$ values, they are higher than for some confined sites (Fig 12). However, the Fe concentration is twice as high as for any other site (even though it is much lower than for many of the Lower Greensand sites). The reason for the high concentration at SS12 is probably related to the relatively complex drift cover in the area. The site is in a permeable 'window' surrounded by clays. This results in abstracted groundwaters that comprise a mixture of reducing and oxic waters.

Carbon system relationships with $\mathrm{CH}_{4}$ concentration (Fig 12) are equally elusive. The amount of change in $\delta^{13} \mathrm{C}_{\mathrm{DIC}}$ is only some $2 \%$, much lower than for the Lower Greensand, indicating fairly minimal water-rock interaction. There is no significant increase in $\mathrm{CH}_{4}$ with time; the ${ }^{14} \mathrm{C}$ age of water at SS9 has been modelled at between 6 and 9 ka (Bath et al, 1979), an age range likely to be reliable precisely because of the lack of 'dead' inorganic carbon additions. There are much older waters down-dip in the Sherwood Sandstone (Bath et al, ibid) but their $\mathrm{CH}_{4}$ contents are unknown.

\subsection{Namurian shales of northern England}

Groundwater is not usually extracted from shales for water supply purposes as both yield and quality tend to be low. However, shales are sometimes tunnelled for water transfer or other purposes. Even though such excavations are normally lined water is liable to leak in, 
sometimes containing elevated amounts of $\mathrm{CH}_{4}$. Two notable cases are the Carsington (Derbyshire) and Wyresdale (Lancashire) tunnels (see Fig 13 for locations), both driven in sequences of sandstones, siltstones and mudstones (colloquially 'shales') of Namurian (Upper Carboniferous) age. In the former case, the $\mathrm{CH}_{4}$ concentrations of inflows averaged $8000 \mu \mathrm{g} / 1$ (Pearson and Edwards, 1989) and in the latter $9000 \mu \mathrm{g} / 1$ (Bath et al, 1988); see Fig 14. However, supporting hydrogeochemical data are only available for the Wyresdale Tunnel (Table 6).

Although there are no Eh and DO data owing to difficulties in sampling the tunnel inflows without atmospheric contact, it is apparent from Table 5 that redox conditions are such that $\mathrm{SO}_{4}$ has been completely reduced. However, this has not led to the development of very high Fe concentrations, probably because of precipitation of $\mathrm{FeS}_{2}$. As far as inorganic carbon is concerned, both $\mathrm{HCO}_{3}$ and $\delta^{13} \mathrm{C}_{\mathrm{DIC}}$ become enriched as $\mathrm{CH}_{4}$ concentrations rise, which suggests that dissolution of calcite is responsible rather than outgassing of $\mathrm{CO}_{2}$ (Bath et al, 1988).

\subsection{Thermal waters: Buxton, Bath and Southampton}

The only surface manifestations of thermal water in Britain are related to the Carboniferous Limestone. It appears that this formation is capable of 'short-circuiting' the natural circulation of water to significant depths in such a way that it reaches the surface rapidly enough to preserve at least some of the heat imparted to the water by the geothermal gradient at depth. This is the mode of operation of the Buxton $\left(27^{\circ} \mathrm{C}\right)$ and Bath $\left(46^{\circ} \mathrm{C}\right)$ springs (see Fig 13 for locations). While hotter waters undoubtedly exist at depth over much of the UK (Downing and Gray, 1986), they are rarely accessible via boreholes. In Southampton, two deep $(2 \mathrm{~km}$ ) boreholes (Marchwood and Western Esplanade) were used to test, and in the case of Western Esplanade produce from, the Triassic Sandstone of the Wessex Basin. The locations of these thermal sites, which had temperatures of 75 and $80^{\circ} \mathrm{C}$ respectively, are shown in Fig 13.

Despite their temperature, the waters of Buxton and Bath are not highly mineralised. However, the Southampton waters have an extremely high TDS (total dissolved solids) content and low redox value (Table 7).

\subsection{Elevated methane contents: higher hydrocarbon and isotopic evidence}

From this survey of natural or baseline $\mathrm{CH}_{4}$ contents, three instances of elevated concentrations stand out: the Stow boreholes of the Lincolnshire Limestone, the deep 
geothermal boreholes in the Triassic at Southampton, and the inflows to tunnels from Namurian shales. Concentrations of $\mathrm{CH}_{4}$ are high enough in these cases to characterise the higher hydrocarbons, and to speculate on the mode of formation of the $\mathrm{CH}_{4}$ using isotopic techniques. Table 8 gives the results of gas and isotopic measurements.

\subsubsection{Lincolnshire Limestone}

The East Midlands has a number of small oilfields which are hosted in the Upper Carboniferous. Some of these are situated beneath the Lincoln area, e.g. Welton and Nettleham. The possibility of upward leakage of oil-associated gas into the Lincolnshire Limestone, was one possible explanation of the high $\mathrm{CH}_{4}$ contents of the 'Stow boreholes' LL5 and LL6. However, examination of the data in Table 8 shows that this is unlikely to be the case. Firstly, although $\mathrm{C}_{2} \mathrm{H}_{6}$ was detected, $\mathrm{CH}_{4}$ made up $99.9 \%$ of the hydrocarbons; such a ratio is much more typical of bacterially-produced gas rather than the 'wet' gas typical of oilfields (e.g. Schoell, 1988). Secondly, the 'light' isotopic content of the $\mathrm{CH}_{4}$ at around $-72 \% \delta^{13} \mathrm{C}$ is also typical of bacterial rather than thermogenic (oil-associated) production. The radiocarbon data from the Stow groundwaters (Table 4) shows that they have been in residence long enough for fermentation processes to have accumulated the necessary amounts of gas. The $\delta^{13} \mathrm{C}_{\mathrm{DIC}}$ values are those expected for old waters in a marine carbonate aquifer (i.e. close to $0 \%$ ), indicating that any methane oxidation occurring via sulphate reduction is having a minimal effect on the isotopic composition of DIC.

\subsubsection{Wessex Basin Sherwood Sandstone}

Some parts of the Wessex basin, particularly a zone some $50 \mathrm{~km}$ to the WSW of Southampton, host commercial oilfields. These produce mainly from Jurassic and Triassic sandstones (Colter and Havard, 1981). During the testing of the Sherwood Sandstone formation in the Marchwood and Western Esplanade boreholes, the relatively high $\mathrm{CH}_{4}$ contents found raised the possibility of a (potentially hazardous) connection with these hydrocarbon-rich zones. The data in Table 8 are at first sight equivocal: the $\mathrm{C}_{2} \mathrm{H}_{6}$ and $\mathrm{C}_{3} \mathrm{H}_{8}$ data show a very 'dry' gas (over $99.9 \% \mathrm{CH}_{4}$ ) typical of bacterial production, but the $\delta^{13} \mathrm{C}_{\mathrm{CH} 4}$ value of around $-46 \%$ resembles that of thermogenic gas.

However, the $\delta^{13} \mathrm{C}_{\mathrm{DIC}}$ values of around $-15.5 \%$ appear much more depleted than would be expected for long-residence groundwaters in this formation: values of around $-8 \%$ would be anticipated if the Sherwood Sandstone of the East Midlands is typical (Bath et al, 1979). A significant amount of acetate fermentation is a likely cause: this has a tendency to raise $\delta^{13} \mathrm{C}_{\mathrm{CH} 4}$ while lowering $\delta^{13} \mathrm{C}_{\mathrm{DIC}}$ values (e.g. Clark and Fritz, 1997). At some $40 \mathrm{mg} / \mathrm{l}$, acetate 
typically contributed one-third of the alkalinity in the Marchwood and Western Esplanade waters (Allen et al, 1983).

\subsubsection{Namurian shales}

While $\mathrm{CH}_{4}$ concentrations in the Wyresdale Tunnel inflows are generally significantly higher than found in the Southampton thermal waters, values of $\delta^{13} \mathrm{C}_{\mathrm{CH} 4}$ are more depleted (average $-67 \%$ ) and $\delta^{13} \mathrm{C}_{\text {DIC }}$ more enriched (average $-12 \%$ ). Bath et al (1988) considered migration of biogenic $\mathrm{CH}_{4}$ from some organic matter source in adjacent strata to be the most likely cause of the high $\mathrm{CH}_{4}$ concentrations, but did not rule out $\mathrm{CO}_{2}$ reduction, because high $p \mathrm{CO}_{2}$ values were measured in inflows on the periphery of the high- $\mathrm{CH}_{4}$ zone. The origin of this $\mathrm{CO}_{2}$ is debatable, but $\mathrm{O}$ and $\mathrm{H}$ stable isotopes confirmed the inflows to be typical of meteoric water, and the peaty upland areas through which rainfall infiltrates were found to have $p \mathrm{CO}_{2}$ values $\geq 10^{-1}$ atm (Bath et al, ibid). Whatever the mechanism of $\mathrm{CH}_{4}$ production at Wyresdale, the similar peak concentration of $\sim 15,000 \mu \mathrm{g} / 1$ at Carsington (Fig 14) suggests a similar mode of formation.

\section{DISCUSSION}

\subsection{The effects of modern perturbations on natural flow regimes}

Before detailed discussion of the results, it is necessary to note that over the past 150 years the natural flow patterns and discharge characteristics of the major water supply aquifers have been distorted by the abstraction of many millions of cubic metres of groundwater. This is likely to have affected the distribution of $\mathrm{CH}_{4}$ within the aquifers, by altering regional flowpaths and causing mixing of different waters. In the absence of detailed output volume records for many of the boreholes considered in this study the effects of magnitude of abstraction cannot be investigated in detail. However, an approximate indication of any effect may be provided by comparing results from water utility pumping stations with those from industrial and domestic supplies. The pumping stations generally have a significantly higher output as they need to supply a large number of consumers.

All Sherwood Sandstone sites are pumping stations while all Lincolnshire Limestone sites are industrial/domestic/observation boreholes. This rules out useful comparisons involving these aquifers. However, Fig 15 shows comparisons between pumping station ('PS') and other sources ('non-PS') for the Chalk and Lower Greensand aquifers, in terms of $\mathrm{CH}_{4}$ concentration versus distance from onset of confinement. In the Chalk, most PS data plot within a narrow concentration band irrespective of whether the borehole is sampling from the 
confined or unconfined aquifer, while in the Lower Greensand PS data show no such pattern. Whether this difference is simply attributable to the different characteristics of the two aquifers (fracture flow for the Chalk, intergranular flow for the Lower Greensand) is debatable. However, it does suggest that the type of Chalk abstraction sampled is liable to bias the result to some extent.

\subsection{Redox conditions}

The results of this study shows that detectable $\mathrm{CH}_{4}$ is found almost ubiquitously through a range of aquifers and redox conditions, even in well-oxygenated waters. This indicates that dissolved methane concentrations are not governed simply by redox state. This is perhaps to be expected by analogy with conditions in the atmosphere, where the $\mathrm{CH}_{4}$ ratio (currently 1.75 ppmv in the lower atmosphere) is some 30 orders of magnitude higher than could coexist in thermodynamic equilibrium with free $\mathrm{O}_{2}$ (Lovelock, 1979). Simple solution of atmospheric $\mathrm{CH}_{4}$ at $10^{\circ} \mathrm{C}$ would alone give groundwaters a baseline concentration of just above the detection limit for this study of $0.05 \mu \mathrm{g} / \mathrm{l}$. About one-fifth of the analyses reported here do not exceed $0.1 \mu \mathrm{g} / \mathrm{l}$, so very little methanogenesis would be required to account for such low concentrations.

The reason for the atmospheric excess in $\mathrm{CH}_{4}$ is the continuous input of methane, largely from biogenic sources, together with a low rate of oxidation. To what extent is this disequilibrium reflected in groundwater? The existence of the redox couple $C(-4) / C(+4)$ in the form of dissolved $\mathrm{CH}_{4}$ and $\mathrm{HCO}_{3}$ permits the calculation of theoretical pe (relative electron activity) values against which pe based on measured Eh values can be compared. Figure 16 shows a plot of pe calculated using PHREEQC (Parkhurst and Appelo, 1999) versus pe derived from Eh via the conversion factor given in Appelo and Postma (2005). Most of the data points fall well below the 1:1 line. Not only are the theoretical values typically some 5-6 orders of magnitude above the observed values, but the $r^{2}$ value of only 0.11 for the best-fit line through the data shows there is little consistency in this displacement.

\subsection{Substrate sources}

The role of microbial activity in the production of $\mathrm{CH}_{4}$ (and in changing the concentrations of the redox parameters $\mathrm{SO}_{4}$ and $\mathrm{Fe}$ ) is obviously important. It was reported by Zobell and Grant (1942) that a DOC concentration as low as $0.1 \mathrm{mg} / \mathrm{L}$ was sufficient to meet microbial requirements. The median DOC concentration in each of the four water-supply aquifers is likely to be at least an order of magnitude greater than this (for example, median values of 1.4 
and $2.1 \mathrm{mg} / 1$ for the Chalk and Sherwood Sandstone respectively are reported by Hinsby et al, 2002), so in that sense the potential for methanogenesis is almost always present.

Thurman (1985) suggests that groundwater DOC either originates in the soil zone or via solubilisation of compounds associated with the rock matrix. The occurrence of organic matter in the three major English aquifers was reviewed by Foster et al (1991). Organic carbon content (\% weight) ranges of $0.05-0.5$ are reported for Chalk; $0.02-0.05$ for Triassic sandstone; and $0.2-2$ for Jurassic Limestone. Similar ranges for chalk and sandstone were found by Harrold et al (2003). A study of chalk from eastern England and northern France (Pacey, 1989) found a diffuse distribution of organic matter, some being intra-crystalline in the calcite, some being associated with clays. Whitelaw and Edwards (1980) found concentrations of carbohydrates up to $0.03 \%$ by weight in the matrix of shallow unsaturated zone Chalk. The origin of the carbohydrate was considered to be organic material in the overlying soil. Low concentrations of bitumens and kerogens have been found on fracture surfaces in limestone (Lawrence and Foster, 1986). All of this evidence suggests the biologically viable DOC in English groundwaters is likely to originate from the soil as the organic matter present in the matrix is mostly unavailable to micro-organisms.

Most DOC that travels from the soil zone to deep within the aquifer will be old and highly recalcitrant, and therefore not prone to further microbial breakdown over the timescales of more active groundwater circulation. Accordingly, $\mathrm{CH}_{4}$ formed microbially is most likely to be produced in shallow groundwaters where redox conditions permit. This is likely to be around anaerobic microsites as proposed by Murphy et al (1992). The redox state in parts of an aquifer can also be lowered by sulphate reduction and pyrite formation, for example as shown to occur in the Chalk aquifer beneath North London by Kimblin and Johnson (1992). This could enable methanogenesis, although necessarily on a limited scale requiring specific circumstances and a definite sequence of events. In the usually oxidising environments of most shallow English aquifers, therefore, $\mathrm{CH}_{4}$ will only be produced at the extremely low concentrations observed. The exception to this would be under conditions only likely to result from localised anthropogenic contamination such as petroleum hydrocarbon spillages or landfill/waste store leachates (e.g. Baedecker and Back, 1979; Christensen et al, 2001; Gooddy et al, 2002) where many of the required TEAPs are provided by the pollutant. In this case the redox potential is lowered considerably although a complete redox sequence may not necessarily exist. 
Common to many trace organic compounds such as pesticides (Gooddy et al, 2001), the transport of methane from the surface may involve sorption to colloidal particles (Ryan and Elimelech, 1996). This may preserve low concentrations of $\mathrm{CH}_{4}$ by helping to prevent oxidation.

As far as the high- $\mathrm{CH}_{4}$ waters are concerned, while in the organic-rich Namurian shales and to a lesser extent the Lincolnshire Limestone there is ample scope for methanogenic bacteria to flourish, the source of the acetate substrate in the Southampton thermal brines is less immediately clear, because the Sherwood Sandstone itself is typically organic-poor on account of its desert origins (Duff and Smith, 1992). However, it was the view of Downing and Penn (1992) that dewatering of the overlying aquiclude formations during subsidence of the Wessex Basin must have contributed substantially to the presently-observed brine content, and it seems possible that this could also have been the ultimate source of the acetate. The high temperature of the water would have assisted in the breakdown of the more refractory organic compounds.

\subsection{Timescales of accumulation}

Although microbial populations have been found in some deep fractured hard rock aquifers (Hama et al 2001), the small pores of Chalk and sandstone aquifers predominant in England will tend to minimise deep transport of most micro-organisms (West and Chilton, 1997; Bloomfield et al, 2001). Any micro-organisms that do exist deep in the aquifer (possibly transported through fractures rather than the matrix) must survive on a highly refractory carbon source such as degraded humic matter from the soil or water-insoluble kerogens (Tissot and Welte, 1984). Therefore only in the longer-residence groundwaters would significant methanogenesis be likely to occur. If there were a relatively simple 'piston flow' of water then a relationship between residence time and $\mathrm{CH}_{4}$ concentration might be expected. For the water-supply aquifers, there is little evidence from ${ }^{14} \mathrm{C}_{\mathrm{DIC}}$ data (or ${ }^{14} \mathrm{C}_{\mathrm{DOC}}$ where available) for the time-related build up of $\mathrm{CH}_{4}$. There is ample scope for mixing in fractured limestone aquifers such as the Chalk and particularly the Lincolnshire Limestone (Darling et al, 1997), so a good correlation with age would not be expected for these aquifers.

While it is certainly the case that the highest $\mathrm{CH}_{4}$ concentrations in the Chalk, Lower Greensand and Lincolnshire Limestone are found among the older waters (there are insufficient data for the Sherwood Sandstone) with bulk ages back to the late Pleistocene, the evidence suggests that in some systems $\mathrm{CH}_{4}$ can build up to close to its final concentration on a Holocene timescale (i.e. $<10 \mathrm{ka}$ BP). The most consistent data from this study, for the 
Lower Greensand (Fig 6), show a well-correlated $\mathrm{CH}_{4}$ build-up occurring until a ${ }^{14} \mathrm{C}$ value of $\sim 20$ pmc, equating to an approximate age of $7 \mathrm{ka}$ (Evans et al, 1979).

However, little is known about the residence time of waters with $\mathrm{CH}_{4}$ concentrations above $1000 \mu \mathrm{g} / \mathrm{l}$. There are no ${ }^{14} \mathrm{C}$ data for the Wyresdale inflows or the Southampton waters (though it is likely the latter have been in residence for several millions of years: Edmunds, 1986). The ${ }^{14} \mathrm{C}$ activities for the high- $\mathrm{CH}_{4}$ sites LL5 and LL6 in the Lincolnshire Limestone do not have the lowest measured values (Table 4), and in addition could be affected by methanogenesis (Bishop and Lloyd, 1990). If from 'dead' organic carbon in the aquifer matrix, this would make the water appear older than it actually is. However, there is no sign of the anomalously positive $\delta^{13} \mathrm{C}_{\text {DIC }}$ values often associated with methanogenesis (Barker and Fritz, 1981).

The production of $\mathrm{CH}_{4}$ is obviously influenced by redox conditions in addition to residence time, and the relative contribution of each factor cannot be resolved with the present data.

\subsection{Hydrochemical screening for methane}

Methane is not routinely measured in groundwaters. Partly this is due to its lack of impact on potable water quality, and partly because rather specialised sampling and analytical methods are required. What pointers to its presence can conventional inorganic hydrochemical analyses provide?

Consideration of redox and carbon system parameters for the four water-supply aquifers shows that there is no single universally-dependable proxy for dissolved $\mathrm{CH}_{4}$ among the commonly-measured hydrochemical determinands. This is not surprising given the thermodynamic disequilibrium demonstrated above. However, since these waters have $\mathrm{CH}_{4}$ concentrations averaging $<10 \mu \mathrm{g} / 1$ (excluding sites LL5 and LL6), methane has little more than trace element status and the lack of predictability is therefore not problematic.

Methane concentrations in excess of $1500 \mu \mathrm{g} / \mathrm{l}$ become of increasing significance to geochemistry (Parkin and Simpkins, 1995; Hansen et al, 2001) and safety (Buswell and Larson, 1937). The small number of measurements available for waters above this concentration in the present study makes statistically-meaningful correlations impossible, but certain tendencies are apparent. For non-thermal waters (LL5, LL6, Wyresdale Tunnel inflows, see Tables 4 and 6), very low $\mathrm{SO}_{4}$ combined with elevated $\mathrm{HCO}_{3}$ is the most obvious clue to potentially high $\mathrm{CH}_{4}$ concentrations. Negative Eh values (where available) reinforce this. For the Southampton thermal waters (Table 7) very low Eh is also a strong indicator, but 
because of the different mode of $\mathrm{CH}_{4}$ formation referred to above, in these cases $\mathrm{SO}_{4}$ is elevated and $\mathrm{HCO}_{3}$ low.

\section{CONCLUSIONS}

The occurrence of $\mathrm{CH}_{4}$ in a variety of groundwater settings has been investigated in terms of its hydrogeochemical context by using redox and carbon system indicators. Methane was present in nearly all groundwaters above the detection limit of $0.05 \mu \mathrm{g} / \mathrm{l}$, but potable waters from the Chalk, Lower Greensand, Lincolnshire Limestone and Sherwood Sandstone possessed (with one exception) only trace concentrations, below $50 \mu \mathrm{g} / \mathrm{l}$ and with an average of $<10 \mu \mathrm{g} / \mathrm{l}$. Concentrations in excess of $1500 \mu \mathrm{g} / \mathrm{l}$ were only found in non-potable waters, the highest values (up to $16,000 \mu \mathrm{g} / \mathrm{l}$ ) being found in tunnel inflows from Namurian shales.

Highest $\mathrm{CH}_{4}$ concentrations were associated with negative Eh potentials, but generally there was at best a tenuous relationship with redox-influenced parameters. A comparison of pe values calculated from the $\mathrm{C}(4) / \mathrm{C}(-4)$ redox couple with those converted from Eh shows that $\mathrm{CH}_{4}$ is very far from being at thermodynamic equilibrium with its surroundings. This is largely due to the bacterial mediation usually involved in $\mathrm{CH}_{4}$ production, i.e. $\mathrm{CO}_{2}$ reduction or (for all potable waters) acetate fermentation. In the latter case, sufficient DOC exists to provide a substrate for bacterial activity, but methanogens are restricted to reducing microsites and productivity is therefore low.

For the high- $\mathrm{CH}_{4}$ waters, stable isotope and higher-hydrocarbon evidence demonstrates that both $\mathrm{CO}_{2}$ reduction and acetate fermentation are possible production routes. Leakage of thermogenic methane from underlying strata has not been identified, but migration of biogenic $\mathrm{CH}_{4}$ from adjacent sources remains a possible factor.

The genesis of $\mathrm{CH}_{4}$ in aquifers seems to occur on two timescales: a rapid if low rate of production from labile carbon in anaerobic microsites, and a much longer, millennium-scale of production via the breakdown of more refractory carbon. However, mixing is likely to affect this simple picture, more particularly in aquifers with fracture porosity (typically the carbonates).

There is no single standard ionic determinand which acts universally as a proxy for high $\mathrm{CH}_{4}$ because modes of production differ with hydrogeological context. However, a combination of high $\mathrm{HCO}_{3}$ and low $\mathrm{SO}_{4}$, or the reverse, indicates a potential methane problem. 


\section{ACKNOWLEDGMENTS}

We thank our colleagues for collecting many of the samples considered in this paper, and Rosemary Hargreaves for producing the map figures. Measurements for ${ }^{14} \mathrm{C}$ in dissolved organic carbon were performed by the NERC Radiocarbon Laboratory, East Kilbride. We are grateful for advice and assistance from David Kinniburgh and Dieke Postma, and for the constructive comments of the Editor, David Rickard, and referees Adrian Bath, Colin Neal and Anonymous. This paper is published with the permission of the Executive Director, British Geological Survey (NERC).

\section{REFERENCES}

Allen D J, Barker J A and Downing R A (1983) The production test and resource assessment of the Southampton (Western Esplanade) geothermal well. Rep Investigation of the Geothermal Potential of the UK series, British Geological Survey, 60 pp.

Altnöder A and Hutter E (1981) Methane in ground waters and the related problems at water works in Hungary. In: Quality of Groundwater (Eds W van Duijvenbooden, P Glasbergen, H van Lelyveld), Proc Symp Noordweijkerhout, Netherlands, Elsevier, 1045-1047.

Appelo C A J and Postma D (2005) Geochemistry, Groundwater and Pollution (2 ${ }^{\text {nd }}$ Edn). CRC Press, Boca Raton, 652 pp.

Aravena R, Wassenaar L I and Barker J F (1995) Distribution and isotopic characterization of methane in a confined aquifer in southern Ontario, Canada. Journal of Hydrology 173, 5170.

Baedecker M J and Back W (1979) Modern marine sediments as a natural analog to the chemically stressed environment of a landfill. Journal of Hydrology 43, 393-414.

Barker J A and Foster S S D (1981) A diffusion exchange model for solute movement in fissured porous rock. Quarterly Journal of Engineering Geology 14, 17-24.

Barker J F and Fritz P (1981) The occurrence and origin of methane in some groundwater flow systems. Canadian Journal of Earth Science 18, 1802-1816. 
Bath A H, Edmunds W M and Andrews J N (1979) Palaeoclimatic trends deduced from the hydrochemistry of a Triassic sandstone aquifer, United Kingdom. In Isotope Hydrology 1978, Vol II, IAEA, 545-566.

Bath A H, Darling W G, Hitchman S P, Andrews J N, Cave M R, Green K A and Reeder S (1988) Chemical and stable isotopic analyses of dissolved gases and groundwater seepages collected from Wyresdale Tunnel, November 1987. Rep British Geological Survey WE/88/1.

Berner R A (1981) A new geochemical classification of sedimentary environments. Journal of Sedimentary and Petrology 51, 359-365.

Bishop P K and Lloyd J W (1990) Chemical and isotopic evidence for the hydrogeological processes occurring in the Lincolnshire Limestone. Journal of Hydrology 121, 293-320.

Bishop P K and Lloyd J W (1991) Use of ${ }^{14} \mathrm{C}$ modelling to determine vulnerability and pollution of a carbonate aquifer: the Lincolnshire Limestone, Eastern England. Applied Geochemistry 6, 319-331.

Bloomfield J P, Gooddy D C, Bright M I and Williams P J 2001. Pore-throat size distributions in sandstones and some implications for contaminant hydrogeology. Hydrogeology Journal 9, 219-230.

Buswell A M and Larson T E (1937) Methane in ground waters. Journal of the American Water Works Association 29, 1978-1982.

Chapelle F H (1993) Ground-Water Microbiology and Geochemistry. John Wiley and Sons Publishers, New York. 424 pp.

Christensen T H, Kjeldsen P, Bjerg P L, Jensen D L, Christensen J B, Baun A, Albrechtsen H J, Heron C (2001). Applied Geochemistry 16, 659-718.

Clark I D and Fritz P (1997) Environmental Isotopes in Hydrogeology. Lewis Publishers, Boca Raton, 328pp. 
Coleman D D, Liu C-L and Riley K M (1988) Microbial methane in the shallow Paleozoic sediments and glacial deposits of Illinois. Chemical Geology 71, 23-40.

Conrad R (1999) Contribution of hydrogen to methane production and control of hydrogen concentrations in methanogenic soils and sediments. FEMS Microbiology Ecology 28, 193202.

Colter V S and Havard D J (1981) The Wytch Farm oil field. In: The Petroleum Geology of the Continental Shelf of NW Europe, Institute of Petroleum, 494-503.

Darling W G, Edmunds W M and Smedley P L (1997) The isotopic composition of palaeowaters in the British Isles. Applied Geochemistry 12, 813-829.

Downing R A and Penn I E (1992) Groundwater flow during the development of the Wessex Basin and its bearing on hydrocarbon and mineral resources. Rep British Geological Survey $\mathrm{SD} / 91 / 1,30 \mathrm{pp}$.

Dennis, F, Andrews J N, Parker A and Wolf, M (1997) Stable and radiogenic isotopes in the Chalk aquifer system, England. Applied Geochemistry 12, 763-773.

Downing R A and Gray D A (1986) Review of the geothermal potential of the UK. In: Geothermal Energy: the Potential in the United Kingdom, (Eds R A Downing and D A Gray). HMSO, London, 152-161.

Downing, R A, Smith, D B, Pearson, F J, Monkhouse, R A and Otlet, R L (1977). The age of groundwater in the Lincolnshire Limestone, England and its relevance to the flow mechanism. Journal of Hydrology 33, 201-216.

Duff P M D and Smith A J (eds) (1992) Geology of England and Wales Geological Society, London, $651 \mathrm{pp}$.

Edmunds, W M (1986) Geochemistry of geothermal waters in the UK. In: Geothermal Energy: the Potential in the United Kingdom (Eds R A Downing and D A Gray). HMSO, London, 111-123. 
Edmunds, WM, Miles D L and Cook J M (1984) A comparative study of sequential redox processes in three British aquifers. In: Hydrochemical Balances of Freshwater Systems, Proc Symp Uppsala (ed E. Eriksson). IAHS Publ 150, 55-70.

Edmunds, W M, Cook, J M, Darling, W G, Kinniburgh, D G, Miles, D L, Bath, A H, Morgan-Jones, M and Andrews, J N (1987). Baseline geochemical conditions in the Chalk aquifer, Berkshire, UK: a basis for groundwater quality management. Applied Geochemistry 2, 251-274.

Edmunds W M, Buckley D K, Darling W G, Milne C J, Smedley P L and Williams A T (2001). Palaeowaters in the aquifers of the coastal regions of southern and eastern England. In: Palaeowaters of Coastal Europe (eds W M Edmunds and C J Milne). Geological Society, London, Spec Publ 189, 71-92.

Elliot T, Andrews J N and Edmunds W M (1999). Hydrochemical trends, palaeorecharge and groundwater ages in the fissured Chalk aquifer of the London and Berkshire Basins, UK. Applied Geochemistry 14, 333-363.

Evans G V, Otlet R L, Downing R A, Monkhouse R A and Rae G (1979) Some problems in the interpretation of isotope measurements in United Kingdom aquifers. In Isotope Hydrology 1978, Vol II, IAEA, 679-706.

Foster S S D, Chilton P J and Stuart M E (1991) Mechanisms of groundwater pollution by pesticides. Journal of the Institution of Water and Environmental Management 5, 186-193.

Games L M and $\mathrm{J}$ M Hayes (1976) On the mechanisms of $\mathrm{CO}_{2}$ and $\mathrm{CH}_{4}$ production in natural anaerobic environments. Chapter 5, Environmental Biogeochemistry, V. 1, Carbon, Nitrogen, Phosphorus, Sulfur and Selenium Cycles, J O Nriagu (ed.)., pp. 51-73.

Gooddy D C, Bloomfield J P, Chilton P J, Johnson A C and Williams R J (2001). Assessing herbicide concentrations in the saturated and unsaturated zone of a chalk aquifer in southern England. Ground Water 39, 262-271. 
Gooddy D C, Clay J W and Bottrell S H (2002) Redox-driven changes in pore-water chemistry of the Chalk unsaturated zone beneath unlined cattle slurry lagoons. Applied Geochemistry 17, 903-921.

Gooddy D C and Darling W G (2005) The potential for methane emissions from groundwaters of the UK. Science of the Total Environment 339, 117-126.

Grossman E L, Coffman B K, Fritz S J and Wada H (1989) Bacterial production of methane and its influence on ground-water chemistry in east-central Texas aquifers. Geology 17, 495499.

Hama K, Bateman K, Coombs P, Hards V L, Milodowski A E, West J M, Wetton P D, Yoshida H, Aoki K (2001). Influence of bacteria on rock-water interaction and clay mineral formation in subsurface granitic environments. Clay Minerals 36, 599-613.

Hansen L K, Jakobsen R and Postma D (2001) Methanogenesis in a shallow sandy aquifer, Rømø, Denmark. Geochimica et Cosmochimica Acta 65, 2925-2935.

Harrold G, Gooddy D C, Reid S, Lerner D N and Leharne S A (2003) Changes in interfacial tension of chlorinated solvents following flow through UK soils and shallow aquifer material. Environmental Science and Technology 37, 1919-1925.

Hinsby K, Gooddy D, Witczak S and Aamand J (2002) Baseline organic carbon (TOC/DOC) concentrations in European groundwater. In: Proc. International Symposium on Subsurface Microbiology (eds H J Albrechtsen \& J Aamand), International Society for Subsurface Microbiology, Copenhagen, pp 56.

Hoehler T M, Alperin M J, Albert D B and Martens C S (1994). Field and laboratory studies of methane oxidation in an anoxic marine sediment. Global Biogeochemical Cycles 8, 451463.

Hoehler T M, Alperin M J, Albert D B and Martens C S (1998). Thermodynamic control on $\mathrm{H}_{2}$ concentrations in anoxic sediments. Geochimica et Cosmochimica Acta 62, 1745-1756. 
Hooker P J and Bannon M P (1993) Methane: its occurrence and hazards in construction. CIRIA Publication R130, 140 pp.

HSE (Health and Safety Executive) (2000) Water boreholes: danger from gas evolution. Local Authority Circular No 27/14.

Jakobsen R, Albrechtsen H-J, Rasmussen M, Bay H, Bjerg P L and Christensen T H (1998) $\mathrm{H}_{2}$ concentrations in a landfill leachate plume (Grindsted, Denmark): In situ energetics of terminal electron accepting processes. Environmental Science and Technology 32, 21422148 .

Jakobsen R and Postma D (1999) Redox zoning, rates of sulfate reduction and interactions with Fe-reduction and methanogenesis in a shallow sandy aquifer, Romo, Denmark. Geochimica et Cosmochimica Acta 63, 137-151.

Kelly W R, Matisoff G and Fisher J B (1985) The effects of a gas well blow out on groundwater chemistry. Environmental Geology and Water Science 7, 205-213.

Kimblin R T and Johnson A C (1992). Recent localised sulphate reduction and pyrite formation in a fissured Chalk aquifer. Chemical Geology 100, 119-127.

Kinniburgh D G, Gale I N, Smedley P L, Darling W G, West J M, Kimblin R T, Parker A, Rae J E, Aldous P J and O'Shea M J (1994) The effects of historic abstraction of groundwater from the London Basin aquifers on groundwater quality. Applied Geochemistry 9, 175-195.

Kuivila K M, Murray J W, Devol A H and Novelli P C (1989). Methane production, sulfate reduction and competition for substrates in the sediments of Lake Washington. Geochimica et Cosmochimica Acta 53, 409-416.

Lansdown J M, Quay P D and King S L (1992) $\mathrm{CH}_{4}$ production via $\mathrm{CO}_{2}$ reduction: a source of ${ }^{13} \mathrm{C}$ depleted $\mathrm{CH}_{4}$. Geochimica et Cosmochimica Acta 56, 3493-3503. 
Lawrence A R and Foster S S D (1986) Denitrification in a limestone aquifer in relation to the security of low-nitrate groundwater supplies. Journal of Institution of Water Engineers 40, 159-172.

Lawrence A R, Gooddy D C, Kanatharana P, Meesilp W and Ramnarong V (2000) Groundwater evolution beneath Hat Yai, a rapidly developing city in Thailand. Hydrogeology Journal 8, 564-575.

Lovelock J E (1979) Gaia: A New Look at Life on Earth. Oxford University Press.

Lovley D R and Goodwin S (1988) Hydrogen concentrations as an indicator of the predominant electron-accepting reactions in aquatic sediments. Geochimica et Cosmochimica Acta 52, 2993-3003.

Miles C J, Tuschall Jr J R and Brezonik L (1983) Isolation of aquatic humus with diethylaminoethylcellulose. Analytical Chemistry 55, 410-411.

Murphy E M, Davis S N, Long A, Donahue D, Jull A J T (1989) ${ }^{14} \mathrm{C}$ in fractions of dissolved organic carbon in ground water. Nature 337, 153-155.

Murphy E M, Schramke J A, Fredrickson J K, Bledsoe H W, Francis A J, Sklarew D S and Linehan J C (1992) The influence of microbial activity and sedimentary organic carbon on the isotope geochemistry of the Middendorf aquifer. Water Resources Research 28, 723-740.

Neal C and Stanger G (1983) Hydrogen generation from mantle source rocks in Oman. Earth \& Planetary Science Letters 66, 315-320.

Pacey N R (1989) Organic matter in Cretaceous chalks from eastern England. Chemical Geology 75, 191-208.

Parkhurst D L and Appelo C A J (1999) User's guide to PHREEQC (Version 2)-A computer program for speciation, batch-reaction, one-dimensional transport, and inverse geochemical calculations: U.S. Geological Survey Water-Resources Investigations Report 99-4259, 310 p. 
Parkin T B and Simpkins W W (1995) Contemporary groundwater methane production from Pleistocene carbon. Journal of Environmental Quality 24, 367-372.

Pearson F and Edwards J S (1989) Methane entry into the Carsington Aqueduct system. Paper 4.3 in: Methane - Facing the Problems, Proc Symp Nottingham, 26-28 Sept 1989.

Price M (1987) Fluid flow in the Chalk of England. In: Fluid Flow in Sedimentary Basins and Aquifers (eds J C Goff \& B P J Williams), Geological Society, London, Spec Publ 34, 141156.

Ryan J N and Elimelech M (1996) Colloid movement and transport in groundwater. Colloids and Surfaces A - Physicochemical and Engineering Aspects 107, 1-56.

Schoell M (1988) Multiple origins of methane in the Earth. Chemical Geology 71, 1-10.

Selley R C (1992) Petroleum seepages in Great Britain. Marine and Petroleum Geology 9, 226-244.

Sherwood B A, Fritz P, Frape S K, Macko S A, Weise S M, Welhan J A (1988). Methane occurrences in the Canadian Shield. Chemical Geology 71, 223-236.

Smith D B, Downing R A, Monkhouse R A, Otlet R L and Pearson F J (1976) The age of groundwater in the Chalk of the London Basin. Water Resources Research 12, 392-404.

Smith R L, Howes B L and Garabedian S P (1991) In situ measurement of methane oxidation in groundwater by using natural-gradient tracer tests. Applied and Environmental Microbiology 57, 1997-2004.

Thurman E M (1985) Organic geochemistry of natural waters, Martinus Nijhoff, Dordrecht, $497 \mathrm{pp}$.

Tissot B P and Welte D H (1984). Petroleum Formation and Occurrence. Springer-Verlag, Berlin, 699 pp. 
TWA (Thames Water Authority) (1986) A survey of dissolved methane levels in raw water from operational wells and boreholes. Central Div Tech Services Rep CD/TEC/TALL/17, $9 \mathrm{pp}$.

Vinten A J A, Castle K and Arah J R M (1996) Field evaluation of models of denitrification linked to nitrate leaching for aggregated soil. European Journal of Soil Science 47, 305-317.

West J M and Chilton P J (1997) Aquifers as environments for microbiological activity. Quarterly Journal of Engineering Geology 30, 147-154.

Whitelaw K and Edwards R A (1980) Carbohydrates in the unsaturated zone of the Chalk, England. Chemical Geology 29, 281-291.

Whiticar M J (1999) Carbon and hydrogen isotope systematics of bacterial formation and oxidation of methane. Chemical Geology 161, 291-314.

Whiticar M J, Faber E and Schoell M (1986) Biogenic methane in marine and freshwater environments: $\mathrm{CO}_{2}$ reduction vs. acetate fermentation - Isotopic evidence. Geochimica et Cosmochimica Acta 50, 693-709.

Zobell C E and Grant CW (1942) Bacterial activity in dilute nutrient solutions. Science 96, 189. 
Table 1 Dissolved methane, redox and carbon-system measurements for sites in the Chalk aquifer of the wider London Basin. Radiocarbon data sources as indicated. NGR - National Grid Reference, PS - pumping station, OB - observation borehole.

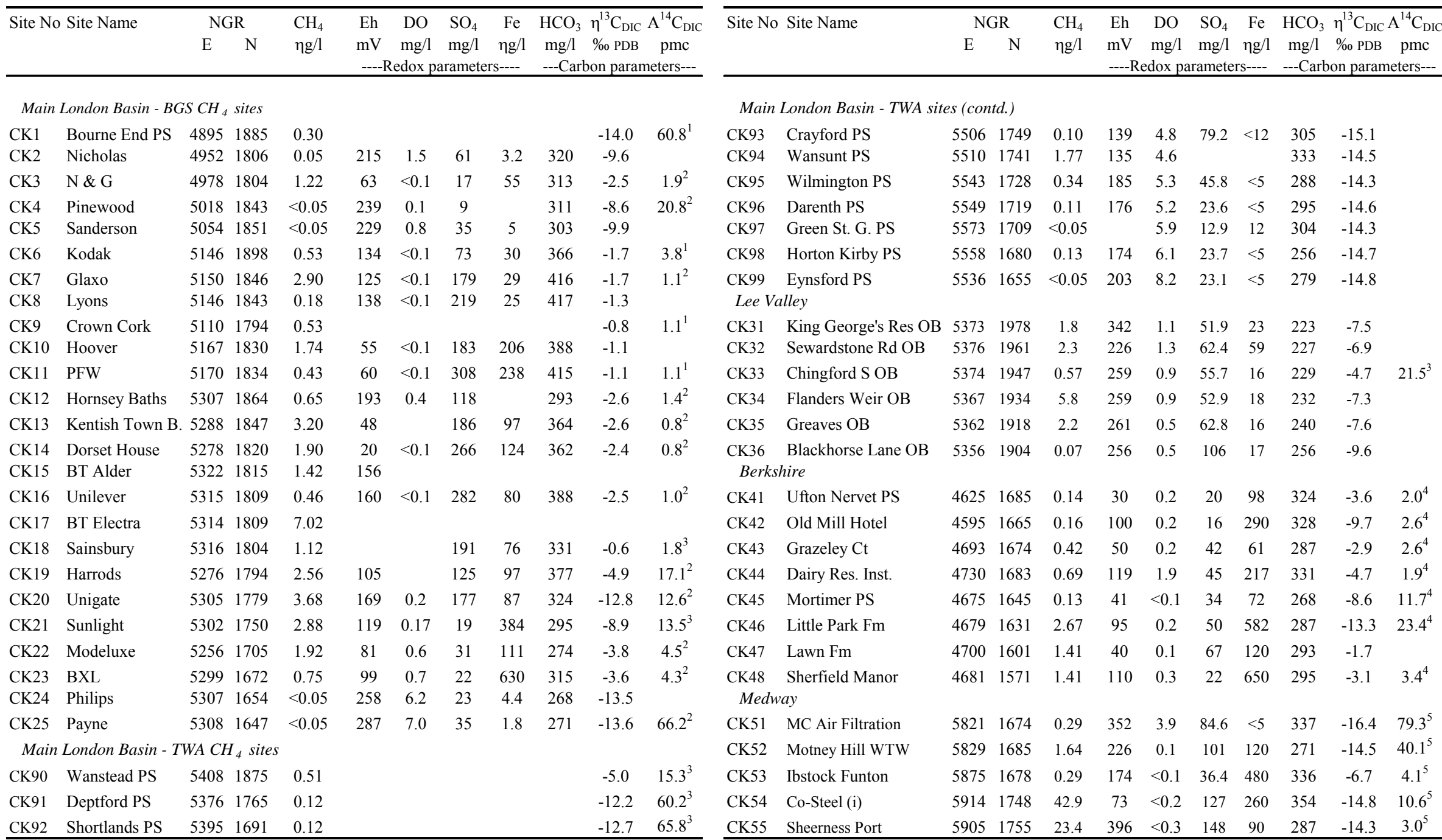

${ }^{1}$ Smith et al (1976) ${ }^{2}$ Elliot et al (1999) ${ }^{3}$ Dennis et al (1997) ${ }^{4}$ Edmunds et al (1987) ${ }^{5}$ Edmunds et al (2001) 
Table 2 Results of ${ }^{14} \mathrm{C}_{\mathrm{DOC}}$ analysis of waters from the Berkshire Chalk, with ages (in ka BP) based on simple correction from pmc (percent modern carbon) values, assuming $A o=100$ pmc (i.e. no dilution factor).

\begin{tabular}{llccccc}
\hline Site No & Site Name & $\mathrm{CH}_{4}$ & $\delta^{13} \mathrm{C}_{\text {DIC }}$ & $\mathrm{A}^{14} \mathrm{C}_{\text {DIC }}$ & \multicolumn{2}{c}{$\mathrm{A}^{14} \mathrm{C}_{\mathrm{DOC}}$} \\
& & $\mu \mathrm{g} / \mathrm{l}$ & $\%$ \%DB & $\mathrm{pmc}$ & $\mathrm{pmc}$ & $\mathrm{ka}$ \\
\hline $\mathrm{CK} 41$ & Ufton Nervet PS & 0.14 & -3.6 & 2.0 & 59.4 & 4.2 \\
$\mathrm{CK} 42$ & Old Mill Hotel & 0.16 & -9.7 & 2.6 & 38.9 & 7.6 \\
$\mathrm{CK}_{3}{ }^{1}$ & Grazeley Court Fm & 0.42 & -2.1 & 1.1 & 43.6 & 6.7 \\
CK45 & Mortimer PS & 0.13 & -8.6 & 11.7 & 33.5 & 8.8 \\
CK46 & Little Park Fm & 2.67 & -13.3 & 23.4 & 41.1 & 7.2 \\
\hline
\end{tabular}

${ }^{\mathrm{I}} \mathrm{CH}_{4}$ concentration from nearby borehole (Grazeley PS) 
Table 3 Dissolved methane, redox and carbon-system measurements for sites in the Lower Greensand and lateral equivalents. NGR - National Grid Reference.

\begin{tabular}{|c|c|c|c|c|c|c|c|c|c|c|c|}
\hline \multirow[t]{3}{*}{ Site No } & \multirow[t]{3}{*}{ Site Name } & \multicolumn{2}{|c|}{ NGR } & \multirow{3}{*}{$\begin{array}{l}\mathrm{CH}_{4} \\
\square \mathrm{g} / 1\end{array}$} & \multirow{2}{*}{$\begin{array}{l}\mathrm{Eh} \\
\mathrm{mV}\end{array}$} & \multirow{2}{*}{$\begin{array}{c}\mathrm{DO} \\
\mathrm{mg} / \mathrm{l}\end{array}$} & \multirow{2}{*}{$\begin{array}{l}\mathrm{SO}_{4} \\
\mathrm{mg} / 1\end{array}$} & \multirow{2}{*}{$\begin{array}{c}\mathrm{Fe} \\
\square \mathrm{g} / 1\end{array}$} & \multirow{2}{*}{$\begin{array}{c}\mathrm{HCO}_{3} \\
\mathrm{mg} / \mathrm{l}\end{array}$} & \multirow{2}{*}{$\begin{array}{l}\square^{13} \mathrm{C}_{\mathrm{DIC}} \\
\% \text { PDB }\end{array}$} & \multirow{2}{*}{$\begin{array}{c}\mathrm{A}^{14} \mathrm{C}_{\mathrm{DIC}} \\
\mathrm{pmc}\end{array}$} \\
\hline & & \multirow{2}{*}{$\mathrm{E}$} & \multirow[t]{2}{*}{$\mathrm{N}$} & & & & & & & & \\
\hline & & & & & \multicolumn{4}{|c|}{--------Redox parameters--------- } & \multicolumn{3}{|c|}{------Carbon parameters------ } \\
\hline LG1 & Birchmoor PS & 4943 & 2347 & $<0.05$ & 422 & 7.6 & 7.6 & 64 & 21.3 & -19.3 & 86.5 \\
\hline LG2 & Pulloxhill PS & 5080 & 2336 & 0.77 & 170 & $<0.1$ & 45.5 & 2600 & 176 & -13.5 & 42.6 \\
\hline LG3 & Meppershall PS & 5150 & 2371 & 3.97 & 146 & $<0.1$ & 34.5 & 1618 & 226 & & \\
\hline LG4 & Newspring PS & 5211 & 2416 & 7.63 & 138 & $<0.1$ & 53.9 & 996 & 304 & & \\
\hline LG5 & Dunton PS & 5242 & 2448 & 9.93 & 136 & $<0.1$ & 75.9 & 835 & 252 & & \\
\hline LG6 & Delco 2 & 5006 & 2223 & 14.51 & 156 & $<0.1$ & 48.9 & 5510 & 204 & -13.1 & 47.4 \\
\hline LG7 & Delco 1 & 5007 & 2213 & 1.68 & 199 & 0.1 & 66.1 & 6510 & 199 & -13.1 & 54.1 \\
\hline LG8 & Slough Est. 7 & 4947 & 1820 & 12.88 & 86 & $<0.1$ & 73 & 138 & 221 & -10.1 & 0.1 \\
\hline LG9 & Slough Est. 10 & 4947 & 1820 & 18.84 & 154 & $<0.1$ & 78 & 9 & 218 & -9.8 & 2.4 \\
\hline LG10 & Slough Est. 12 & 4949 & 1820 & 10.45 & 74 & $<0.1$ & 49.3 & 121 & 266 & -11.1 & 0.1 \\
\hline LG11 & Horlicks 5 & 4973 & 1804 & 22.0 & 4 & $<0.1$ & 34.8 & 182 & 240 & -11.5 & 2.1 \\
\hline LG12 & Boxalls Lane PS & 4863 & 1493 & 13.33 & 131 & 0.1 & 15.8 & 140 & 144 & -16.1 & 1.2 \\
\hline LG13 & Tongham Moor PS & 4883 & 1493 & 3.09 & 158 & 0.1 & 14.4 & 154 & 146 & -16.3 & 0.5 \\
\hline LG14 & Tongham PS & 4878 & 1484 & 8.13 & 151 & 0.1 & 16.9 & 205 & 146 & -16.2 & 3.1 \\
\hline LG15 & Oakhanger PS & 4736 & 1361 & 4.03 & 299 & $<0.1$ & 7.2 & 249 & 131 & -17.3 & 35.1 \\
\hline LG16 & Bourne PS & 4846 & 1450 & 2.56 & & 0.4 & 36.5 & 3820 & 224 & -12.1 & 37.1 \\
\hline LG17 & Tilford Meads PS & 4875 & 1435 & 3.81 & 177 & $<0.1$ & 12.4 & 347 & 141 & -11.3 & 24.4 \\
\hline LG18 & Mousehill PS & 4939 & 1417 & 11.86 & 94 & $<0.1$ & 16.3 & 506 & 162 & -12.4 & 37.2 \\
\hline LG19 & Netley Mill PS & 5077 & 1476 & 0.56 & 258 & 6.5 & 25.7 & 616 & 94.6 & -12.0 & 72.5 \\
\hline LG20 & Akzo Nobel & 5778 & 1694 & 7.70 & 364 & 5 & 18.9 & 20 & 343 & -12.5 & 1.32 \\
\hline
\end{tabular}


Table 4 Dissolved methane, redox and carbon-system measurements for sites in the Lincolnshire Limestone. Data from Bishop \& Lloyd (1990, 1991) except as indicated. NGR - National Grid Reference.

\begin{tabular}{|c|c|c|c|c|c|c|c|c|c|c|c|}
\hline \multirow[t]{3}{*}{ Site No } & \multirow[t]{3}{*}{ Site Name } & \multicolumn{2}{|c|}{ NGR } & \multirow{3}{*}{$\begin{array}{l}\mathrm{CH}_{4} \\
\mu \mathrm{g} / 1\end{array}$} & \multirow{2}{*}{$\begin{array}{l}\text { Eh } \\
\mathrm{mV}\end{array}$} & \multirow{2}{*}{$\begin{array}{c}\mathrm{DO} \\
\mathrm{mg} / \mathrm{l}\end{array}$} & \multirow{2}{*}{$\begin{array}{l}\mathrm{SO}_{4} \\
\mathrm{mg} / 1\end{array}$} & \multirow{3}{*}{$\begin{array}{c}\mathrm{Fe} \\
\mu \mathrm{g} / \mathrm{l}\end{array}$} & \multirow{3}{*}{$\begin{array}{c}\mathrm{HCO}_{3} \\
\mathrm{mg} / \mathrm{l}\end{array}$} & \multirow{2}{*}{$\begin{array}{l}\delta^{13} \mathrm{C}_{\mathrm{DIC}} \\
\% \% \text { PDB }\end{array}$} & \multirow{2}{*}{$\begin{array}{c}\mathrm{A}^{14} \mathrm{C}_{\mathrm{DIC}} \\
\mathrm{pmc}\end{array}$} \\
\hline & & \multirow{2}{*}{$\mathrm{E}$} & \multirow[t]{2}{*}{$\mathrm{N}$} & & & & & & & & \\
\hline & & & & & \multicolumn{3}{|c|}{---------Redox parameters---------- } & & & \multicolumn{2}{|c|}{-----Carbon parameters----- } \\
\hline LL1 & Ropsley Lodge & 4983 & 3355 & 1 & 301 & nd & 76.6 & 46 & 372 & -12.7 & 61.6 \\
\hline LL2 & Ryland & 5032 & 3768 & 1.5 & & nd & 106 & & 309 & -7.4 & \\
\hline LL3 & Dunholme Rd & 5037 & 3764 & 0.05 & 261 & nd & 225 & & 305 & -14.0 & \\
\hline $\mathrm{LL}^{1}$ & Stow 5 & 5063 & 3705 & 32 & & nd & 77.2 & 14800 & 184 & -11.2 & 61.1 \\
\hline $\mathrm{LL}^{2}$ & Stow 4 & 5072 & 3711 & 1700 & -49 & nd & 3.2 & 80 & 723 & -1.5 & 2.9 \\
\hline $\operatorname{LL}^{2}$ & Stow 6 & 5074 & 3699 & 2300 & -109 & nd & 3.6 & 500 & 552 & -2.1 & 2.4 \\
\hline LL7 & Dorrington Fen & 5114 & 3539 & 21.2 & 11 & nd & 2.8 & & 413 & -3.3 & 1.2 \\
\hline LL8 & Digby Fen & 5118 & 3547 & 2.6 & 116 & nd & 122 & & 297 & -10.0 & 47.2 \\
\hline LL9 & Walcott & 5130 & 3565 & 5.3 & 76 & nd & 48.0 & & 280 & -2.4 & 6.5 \\
\hline LL10 & Timberland & 5130 & 3586 & 2.6 & -29 & nd & 56.2 & & 410 & -1.8 & 1.9 \\
\hline LL11 & Pinchbeck W & 5205 & 3250 & 1.4 & 86 & nd & 31.0 & & 395 & -2.0 & \\
\hline LL12 & Donington Caythorpe & 5221 & 3363 & 4.1 & -139 & nd & 31.0 & & 436 & -1.7 & \\
\hline
\end{tabular}

${ }^{1}$ Data from this study ${ }^{2}$ Data other than $\mathrm{CH}_{4}$, Eh and $\mathrm{SO}_{4}$ from this study 
Table 5 Dissolved methane, redox and carbon-system measurements for sites in the Sherwood Sandstone of the East Midlands. NGR - National Grid Reference.

\begin{tabular}{|c|c|c|c|c|c|c|c|c|c|c|c|}
\hline \multirow[t]{3}{*}{ Site No } & \multirow[t]{3}{*}{ Site Name } & \multicolumn{2}{|c|}{ NGR } & \multirow{3}{*}{$\begin{array}{l}\mathrm{CH}_{4} \\
\mu \mathrm{g} / \mathrm{l}\end{array}$} & \multirow{3}{*}{$\begin{array}{l}\text { Eh } \\
\mathrm{mV}\end{array}$} & \multirow{3}{*}{$\begin{array}{c}\mathrm{DO} \\
\mathrm{mg} / \mathrm{l}\end{array}$} & \multirow{2}{*}{$\begin{array}{l}\mathrm{SO}_{4} \\
\mathrm{mg} / \mathrm{l}\end{array}$} & \multirow{3}{*}{$\begin{array}{c}\mathrm{Fe} \\
\mu \mathrm{g} / \mathrm{l}\end{array}$} & \multirow{3}{*}{$\begin{array}{c}\mathrm{HCO}_{3} \\
\mathrm{mg} / \mathrm{l}\end{array}$} & \multirow{2}{*}{$\begin{array}{l}\delta^{13} \mathrm{C}_{\mathrm{DIC}} \\
\% \text { PDB }\end{array}$} & \multirow{2}{*}{$\begin{array}{c}\mathrm{A}^{14} \mathrm{C}_{\mathrm{DIC}} \\
\mathrm{pmc}\end{array}$} \\
\hline & & \multirow{2}{*}{$\mathrm{E}$} & \multirow{2}{*}{$\mathrm{N}$} & & & & & & & & \\
\hline & & & & & & & ameter & & & bon parar & eters----- \\
\hline SS1 & Far Baulker No 1 & 4612 & 3543 & 0.93 & 343 & 8.0 & 45.8 & $<10$ & 109 & -14.0 & 56.0 \\
\hline $\mathrm{SS} 2$ & Halam No 1 & 4670 & 3537 & $<0.05$ & 340 & 7.1 & 5.9 & $<10$ & 135 & -12.2 & 29.6 \\
\hline SS3 & Ompton No 2 & 4678 & 3648 & 2.43 & 419 & 6.7 & 4.9 & $<10$ & 139 & -13.0 & 42.6 \\
\hline SS4 & Whisker Hill & 4692 & 3800 & $<0.05$ & 440 & 5.8 & 30.9 & $<10$ & 109 & -12.9 & 43.3 \\
\hline SS5 & Ordsall No 2 & 4696 & 3802 & $<0.05$ & 358 & 5.7 & 29.5 & $<10$ & 134 & -12.8 & 39.2 \\
\hline SS6 & Markham Clinton & 4711 & 3727 & 1.42 & 357 & 4.9 & 8.4 & $<10$ & 161 & -12.8 & 27.3 \\
\hline SS7 & Hayton No 1 & 4729 & 3854 & $<0.05$ & 102 & $<0.1$ & 58.9 & 121 & 213 & -12.5 & 16.6 \\
\hline SS8 & Grove No 2 & 4741 & 3804 & $<0.05$ & 90 & $<0.1$ & 31.7 & 191 & 204 & -12.4 & 17.3 \\
\hline SS9 & Caunton No 2 & 4739 & 3601 & 1.93 & 2 & $<0.1$ & 32.6 & 191 & 249 & -13.0 & 21.1 \\
\hline SS10 & Nutwell No 3 & 4634 & 4031 & 2.5 & 382 & $<0.1$ & 27.6 & $<10$ & 151 & -13.4 & \\
\hline SS11 & Thornham No 3 & 4655 & 4033 & $<0.05$ & 155 & $<0.1$ & 48.9 & $<10$ & 232 & -13.8 & \\
\hline SS12 & Boston Park No 1 & 4677 & 4046 & 465 & 120 & $<0.1$ & 23.3 & 370 & 223 & -14.1 & \\
\hline
\end{tabular}


Table 6 Dissolved methane, redox and carbon-system measurements for sites in the Wyresdale Tunnel, Lancashire. All data from Bath et al (1988).

\begin{tabular}{lccccc}
\hline $\begin{array}{c}\text { Sample point } \\
\text { metres }\end{array}$ & $\begin{array}{c}\mathrm{CH}_{4} \\
\mu \mathrm{g} / \mathrm{l}\end{array}$ & $\begin{array}{c}\mathrm{SO}_{4} \\
\mathrm{mg} / \mathrm{l} \\
\text { Redox parameters }\end{array}$ & $\begin{array}{c}\mathrm{Fe} \\
\mathrm{g} / \mathrm{l}\end{array}$ & $\begin{array}{c}\mathrm{HCO}_{3} \\
\mathrm{mg} / \mathrm{l} \\
\text { Carbon parameters }\end{array}$ & $\begin{array}{c}\delta^{13} \mathrm{C}_{\text {DIC }} \\
\% \text { PDB }\end{array}$ \\
\hline 509 & 2714 & $<2$ & $<20$ & 378 & -12.8 \\
4343 & 16000 & $<2$ & $<20$ & 583 & -8.1 \\
4980 & 3000 & $<2$ & $<20$ & 411 & -13.8 \\
5090 & 13000 & $<2$ & 35 & 417 & -11.6 \\
5340 & 15000 & $<2$ & 24 & 451 & -10.3 \\
5787 & 2429 & $<2$ & 240 & 410 & -15.6 \\
\hline
\end{tabular}

${ }^{1}$ Distance from Rowton (northern) portal 
Table 7 Dissolved methane, redox and carbon-system measurements for thermal waters from Buxton, Bath and Southampton. NGR - National Grid Reference.

\begin{tabular}{|c|c|c|c|c|c|c|c|c|c|c|c|c|}
\hline \multirow[t]{3}{*}{ Site name } & \multicolumn{2}{|c|}{ NGR } & \multirow{3}{*}{$\begin{array}{c}\text { TDS } \\
\mathrm{g} / 1\end{array}$} & \multirow{3}{*}{$\begin{array}{c}\text { Temp } \\
{ }^{\circ} \mathrm{C}\end{array}$} & \multirow{3}{*}{$\begin{array}{l}\mathrm{CH}_{4} \\
\mu \mathrm{g} / \mathrm{l}\end{array}$} & \multirow{2}{*}{$\begin{array}{c}\mathrm{Eh} \\
\mathrm{mV}\end{array}$} & \multirow{2}{*}{$\begin{array}{c}\mathrm{DO} \\
\mathrm{mg} / \mathrm{l}\end{array}$} & \multirow{2}{*}{$\begin{array}{l}\mathrm{SO}_{4} \\
\mathrm{mg} / \mathrm{l}\end{array}$} & \multirow{2}{*}{$\begin{array}{c}\mathrm{Fe} \\
\mu \mathrm{g} / 1\end{array}$} & \multirow{2}{*}{$\begin{array}{c}\mathrm{HCO}_{3} \\
\mathrm{mg} / \mathrm{l}\end{array}$} & \multirow{2}{*}{$\begin{array}{l}\delta^{13} \mathrm{C}_{\mathrm{DIC}} \\
\% \text { PDB }\end{array}$} & \multirow{2}{*}{$\begin{array}{c}\mathrm{A}^{14} \mathrm{C}_{\mathrm{DIC}} \\
\text { pmc }\end{array}$} \\
\hline & \multirow[t]{2}{*}{$\mathrm{E}$} & \multirow[t]{2}{*}{$\mathrm{N}$} & & & & & & & & & & \\
\hline & & & & & & \multicolumn{4}{|c|}{----------Redox parameters---------- } & \multicolumn{3}{|c|}{----Carbon parameters---- } \\
\hline Buxton & 4055 & 3735 & 0.38 & 27.5 & 0.29 & 431 & $<0.1$ & 11.9 & $<10$ & 235 & -8.9 & 18.0 \\
\hline Bath & 3750 & 1647 & 2.3 & 44.8 & 53 & -2 & $<0.1$ & 1080 & 774 & 187 & -1.5 & 2.16 \\
\hline So'ton Marchwood & 4399 & 1112 & 103 & 72.5 & 7790 & -300 & $<0.1$ & 1400 & 4200 & 81 & -15.8 & \\
\hline So'ton W Esplanade & 4416 & 1120 & 124 & 76.0 & 5540 & -200 & $<0.1$ & 1230 & 4100 & 71 & -15.5 & \\
\hline
\end{tabular}


Table 8 Dissolved gas composition and isotope values for high-methane waters in the Lincolnshire Limestone, Wyresdale Tunnel and Southampton geothermal wells.

\begin{tabular}{lcccccc}
\hline Site & $\begin{array}{c}\mathrm{CH}_{4} \\
\mathrm{~cm}^{3} \mathrm{STP} / 1\end{array}$ & $\begin{array}{c}\mathrm{C}_{2} \mathrm{H}_{6} \\
\mathrm{~cm}^{3} \mathrm{STP} / 1 \\
\times 10^{3}\end{array}$ & $\begin{array}{c}\mathrm{C}_{3} \mathrm{H}_{8} \\
\mathrm{~cm}^{3} \mathrm{STP} / 1 \\
\times 10^{3}\end{array}$ & $\begin{array}{c}\mathrm{HCO}_{3} \\
\mathrm{mg} / 1\end{array}$ & $\begin{array}{c}\delta^{13} \mathrm{C}_{\mathrm{DIC}} \\
\% \text { PDB }\end{array}$ & $\begin{array}{c}\delta^{13} \mathrm{C}_{\mathrm{CH} 4} \\
\% \text { \% PDB }\end{array}$ \\
\hline $\begin{array}{c}\text { Wyresdale tunnel } \\
\text { x }\end{array}$ & & & & & & \\
$509 \mathrm{~m}$ & 3.8 & $<0.01$ & $<0.01$ & 378 & -12.8 & -60.3 \\
$4343 \mathrm{~m}$ & 22.4 & 1.1 & $<0.01$ & 583 & -8.1 & -64.3 \\
$4980 \mathrm{~m}$ & 4.2 & $<0.01$ & $<0.01$ & 411 & -13.8 & -66.5 \\
$5090 \mathrm{~m}$ & 18.2 & 3.5 & $<0.01$ & 417 & -11.6 & -67.1 \\
$5340 \mathrm{~m}$ & 21.0 & 0.2 & $<0.01$ & 451 & -10.3 & -72.6 \\
$5787 \mathrm{~m}$ & 3.4 & $<0.01$ & $<0.01$ & 410 & -15.6 & -68.6 \\
$\quad$ Lincolnshire Lst & & & & & -12.0 & -66.6 \\
LL5 & 2.4 & 2.3 & & 723 & -1.5 & -71.8 \\
LL6 & 3.2 & 3.3 & & 552 & -2.1 & -72.6 \\
$\quad$ So'ton geothermal & & & & & & \\
Marchwood & 10.9 & 7.1 & 0.51 & 81 & -15.8 & \\
W Esplanade & 7.8 & 5.3 & 0.25 & 71 & -15.5 & -45.8 \\
\hline
\end{tabular}


Figure 1 Map of the wider London Basin area, showing the outcrop of the Chalk and the location of borehole sampling sites within the London area, Berkshire (S of Reading) and Medway (NE of Maidstone). Site numbers are prefixed with CK when referred to in tables and text. Sites are differentiated according to whether sampled by the British Geological Survey ('BGS') or by the former Thames Water Authority ('TWA').

Figure 2 Plot of dissolved $\mathrm{CH}_{4}$ concentration versus distance from onset of confinement (positive $=$ confined, negative $=$ unconfined) for the Chalk sites in Fig 1. LB London Basin.

Figure 3 Plots of redox-related parameters $\mathrm{Eh}$, dissolved $\mathrm{O}_{2}, \mathrm{SO}_{4}$ and $\mathrm{Fe}$, plus carbonsystem parameters $\mathrm{HCO}_{3}, \delta^{13} \mathrm{C}_{\mathrm{DIC}}$ and ${ }^{14} \mathrm{C}_{\mathrm{DIC}}$ activity, versus dissolved $\mathrm{CH}_{4}$ concentrations in the Chalk aquifer of the wider London Basin.

Figure 4 Map of the outcrop of Lower Greensand and lateral equivalents in SE England, showing the location of borehole sampling sites. Site numbers are prefixed with LG when referred to in table and text. Sites are differentiated according to whether sampled by the British Geological Survey ('BGS') or by the former Thames Water Authority ('TWA').

Figure 5 Plot of dissolved $\mathrm{CH}_{4}$ concentration versus distance from onset of confinement (positive $=$ confined, negative $=$ unconfined) in the Lower Greensand aquifer of SE England.

Figure 6 Plots of redox-related parameters Eh, dissolved $\mathrm{O}_{2}, \mathrm{SO}_{4}$ and Fe, plus carbonsystem parameters $\mathrm{HCO}_{3}, \delta{ }^{13} \mathrm{C}_{\mathrm{DIC}}$ and ${ }^{14} \mathrm{C}_{\mathrm{DIC}}$ activity, versus dissolved $\mathrm{CH}_{4}$ concentrations in the Lower Greensand aquifer of SE England. Note that in contrast to the Chalk, Lincolnshire Limestone and Sherwood Sandstone, the $\mathrm{CH}_{4}$ scale is non-logarithmic, and Fe scale is in $\mathrm{mg} / \mathrm{l}$ rather than $\mu \mathrm{g} / \mathrm{l}$.

Figure 7 Map of the outcrop of the Lincolnshire Limestone in eastern England, showing the location of borehole sampling sites of Bishop and Lloyd (1990). Site numbers are prefixed with LL when referred to in table and text.

Figure 8 Plot of dissolved $\mathrm{CH}_{4}$ concentration versus distance from onset of confinement (positive $=$ confined, negative $=$ unconfined) in the Lincolnshire Limestone aquifer of eastern England. 
Figure 9 Plots of redox-related parameters Eh and $\mathrm{SO}_{4}$, plus carbon-system parameters $\mathrm{HCO}_{3}, \delta^{13} \mathrm{C}_{\text {DIC }}$ and ${ }^{14} \mathrm{C}_{\text {DIC }}$ activity, versus dissolved $\mathrm{CH}_{4}$ concentrations in the Lincolnshire Limestone aquifer of eastern England.

Figure 10 Map of the outcrop of the Sherwood Sandstone in eastern England, showing the location of borehole sampling sites. Site numbers are prefixed with SS when referred to in table and text.

Figure 11 Plot of dissolved $\mathrm{CH}_{4}$ concentration versus distance from onset of confinement (positive $=$ confined, negative $=$ unconfined) in the Sherwood Sandstone aquifer of eastern England.

Figure 12 Plots of redox-related parameters $\mathrm{Eh}$, dissolved $\mathrm{O}_{2}, \mathrm{SO}_{4}$ and $\mathrm{Fe}$, plus carbonsystem parameters $\mathrm{HCO}_{3}, \delta^{13} \mathrm{C}_{\mathrm{DIC}}$ and ${ }^{14} \mathrm{C}_{\mathrm{DIC}}$ activity, versus dissolved $\mathrm{CH}_{4}$ concentrations in the Sherwood Sandstone aquifer of eastern England.

Figure 13 Location of thermal water and high- $\mathrm{CH}_{4}$ sites (excluding LL5 and LL6 - see Fig 7).

Figure 14 Plot of dissolved $\mathrm{CH}_{4}$ concentrations in the Wyresdale (Lancashire) and Carsington (Derbyshire) water transfer tunnels. Both tunnels are bored in Namurian strata and show comparable levels of $\mathrm{CH}_{4}$.

Figure 15 Plot of dissolved $\mathrm{CH}_{4}$ concentrations in Chalk and Lower Greensand boreholes versus distance from onset of confinement, differentiating between highabstraction pumping station (PS) and other sources (non-PS).

Figure 16 Plot of pe values calculated from the redox couple $C(4) / C(-4)$ versus pe derived from field Eh measurements for samples from the Chalk, Lower Greensand and Lincolnshire Limestone aquifers, indicating the sizeable departure from thermodynamic equilibrium for dissolved $\mathrm{CH}_{4}$. 


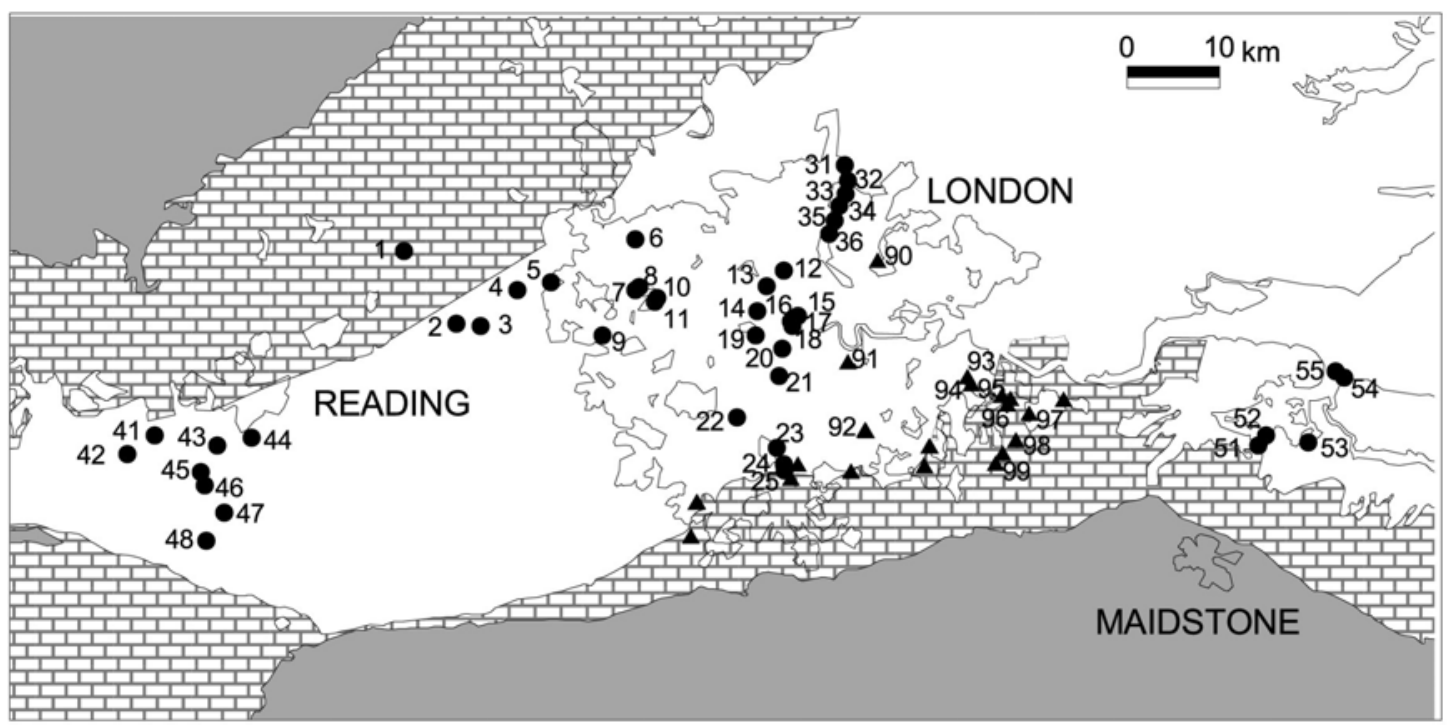

\begin{tabular}{l}
\hline Overlying formations \\
Chalk \\
Underlying formations
\end{tabular}

- Sampling sites (BGS)

- Sampling sites (TWA)

Figure 1 


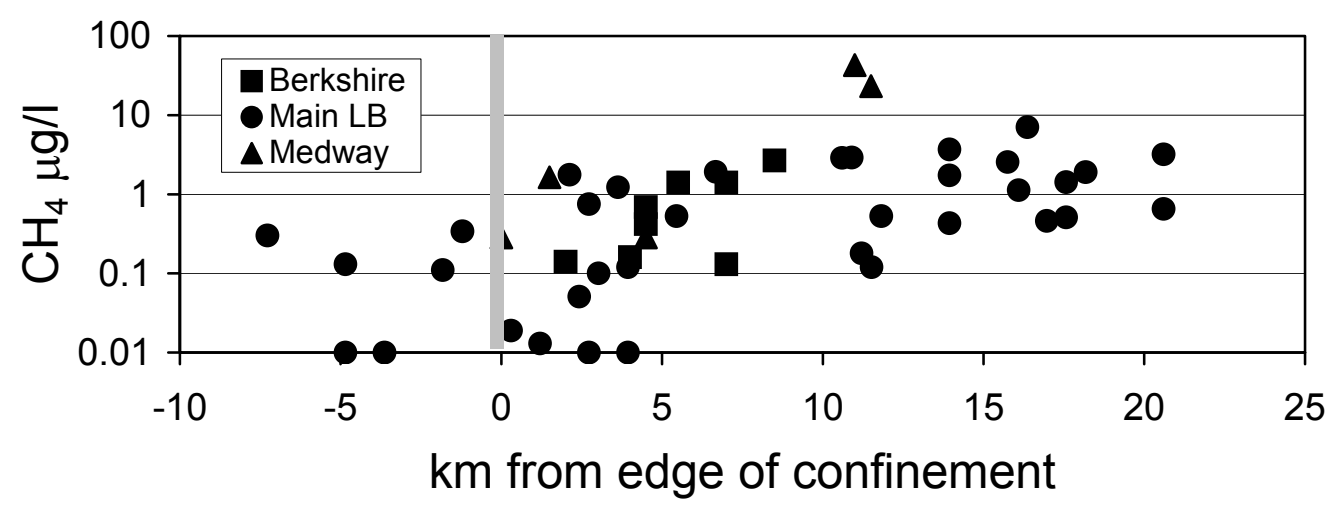

Figure 2 

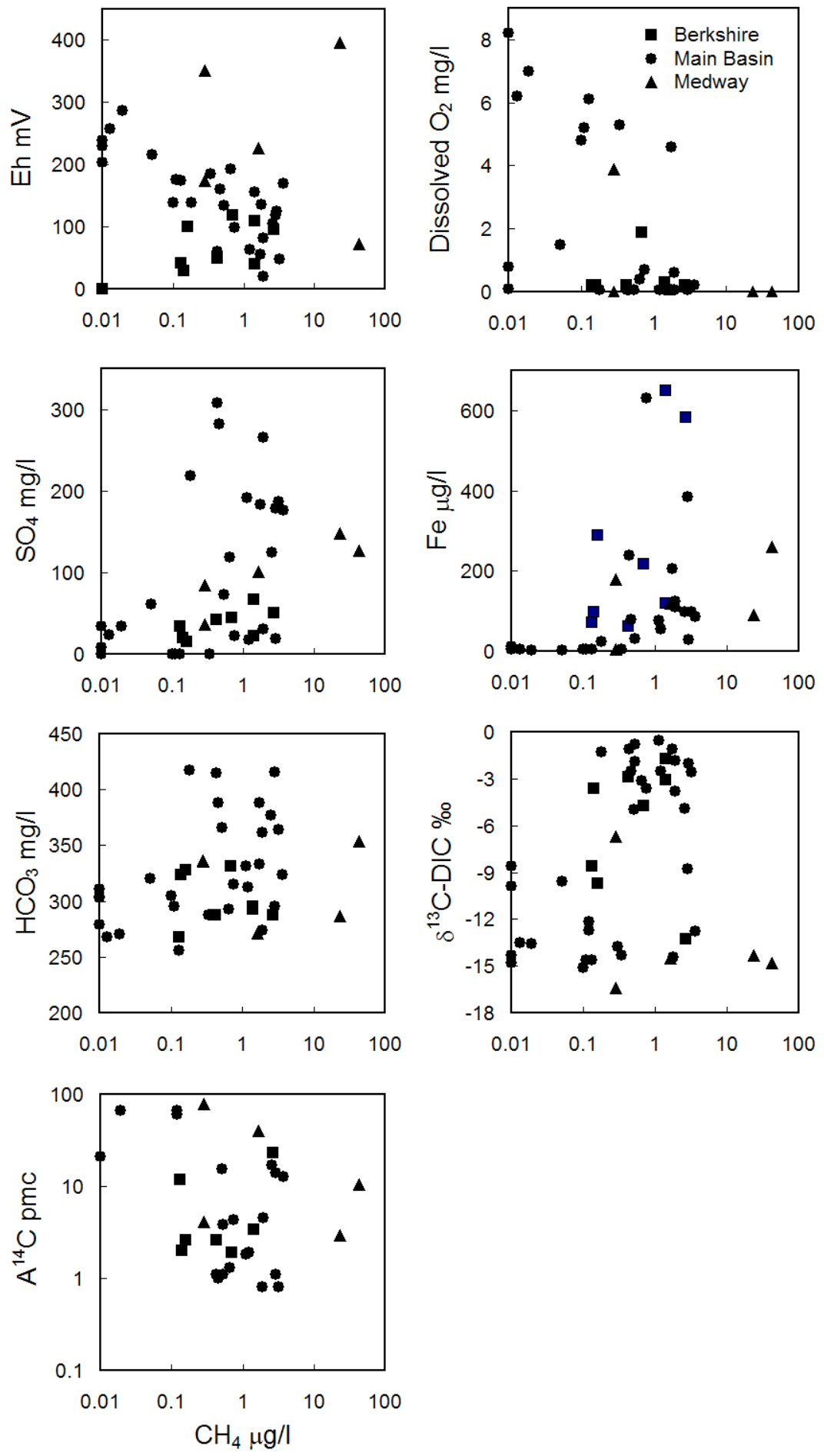

Figure 3 


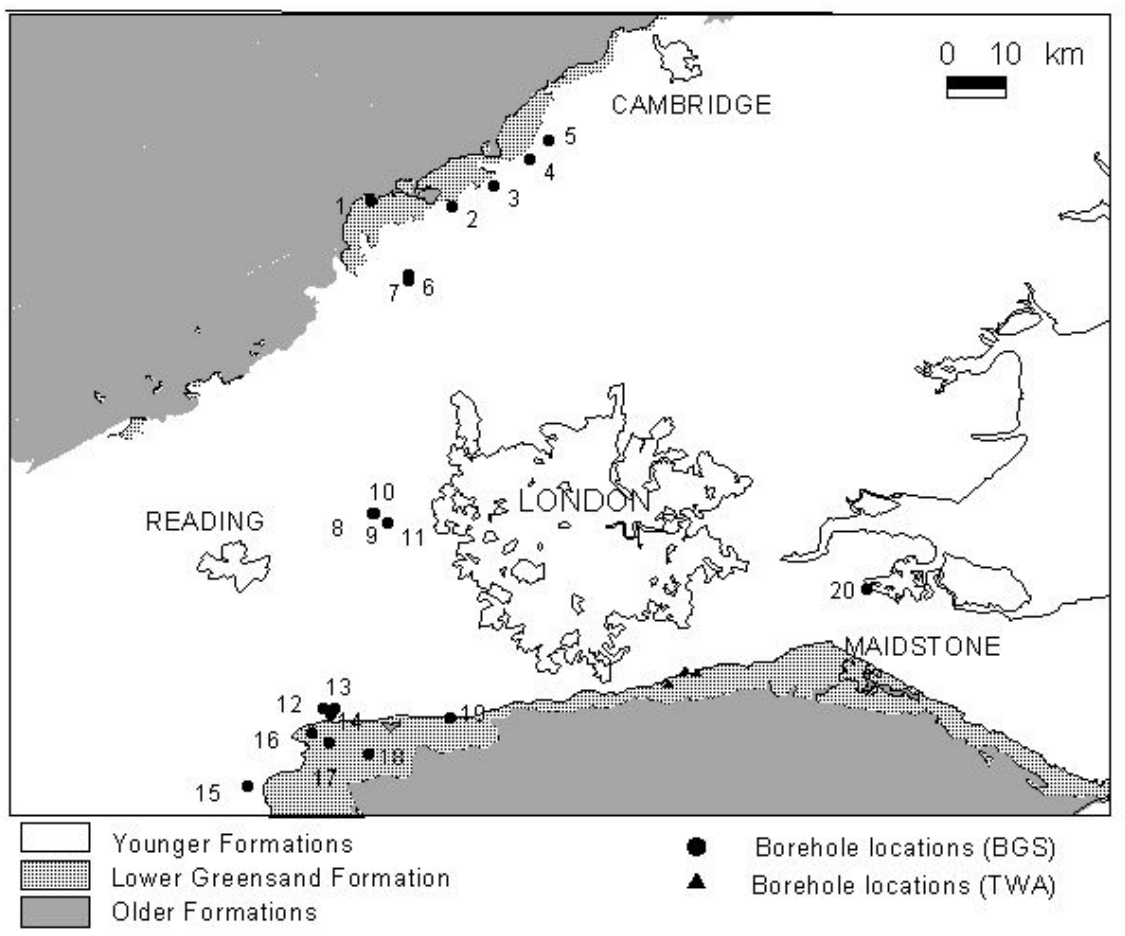

Figure 4 


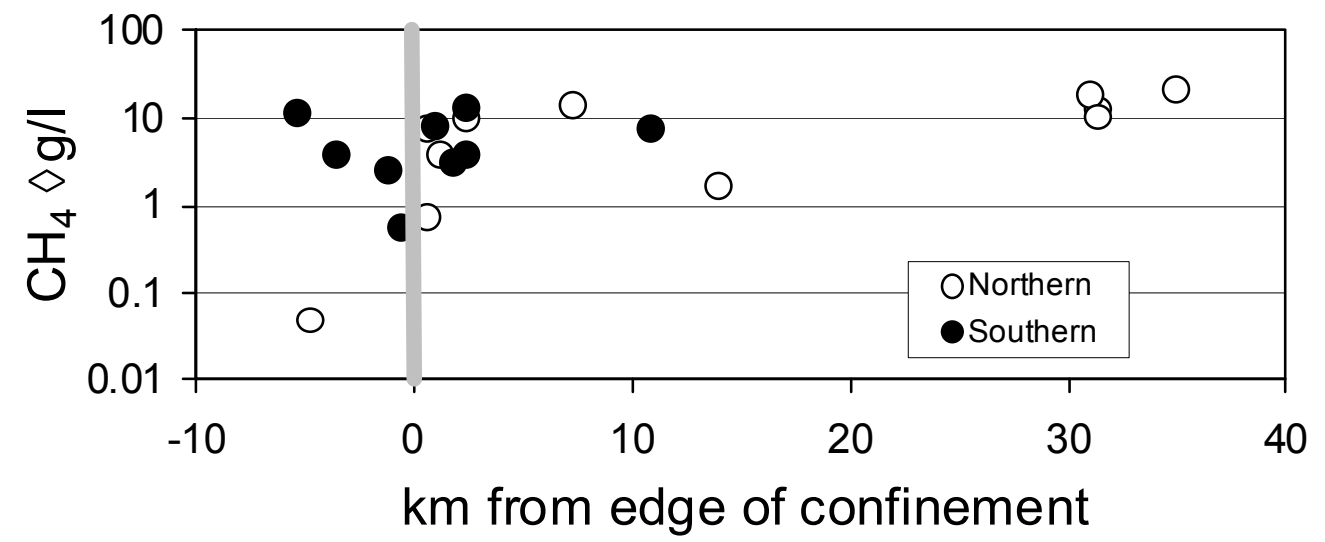

Figure 5 

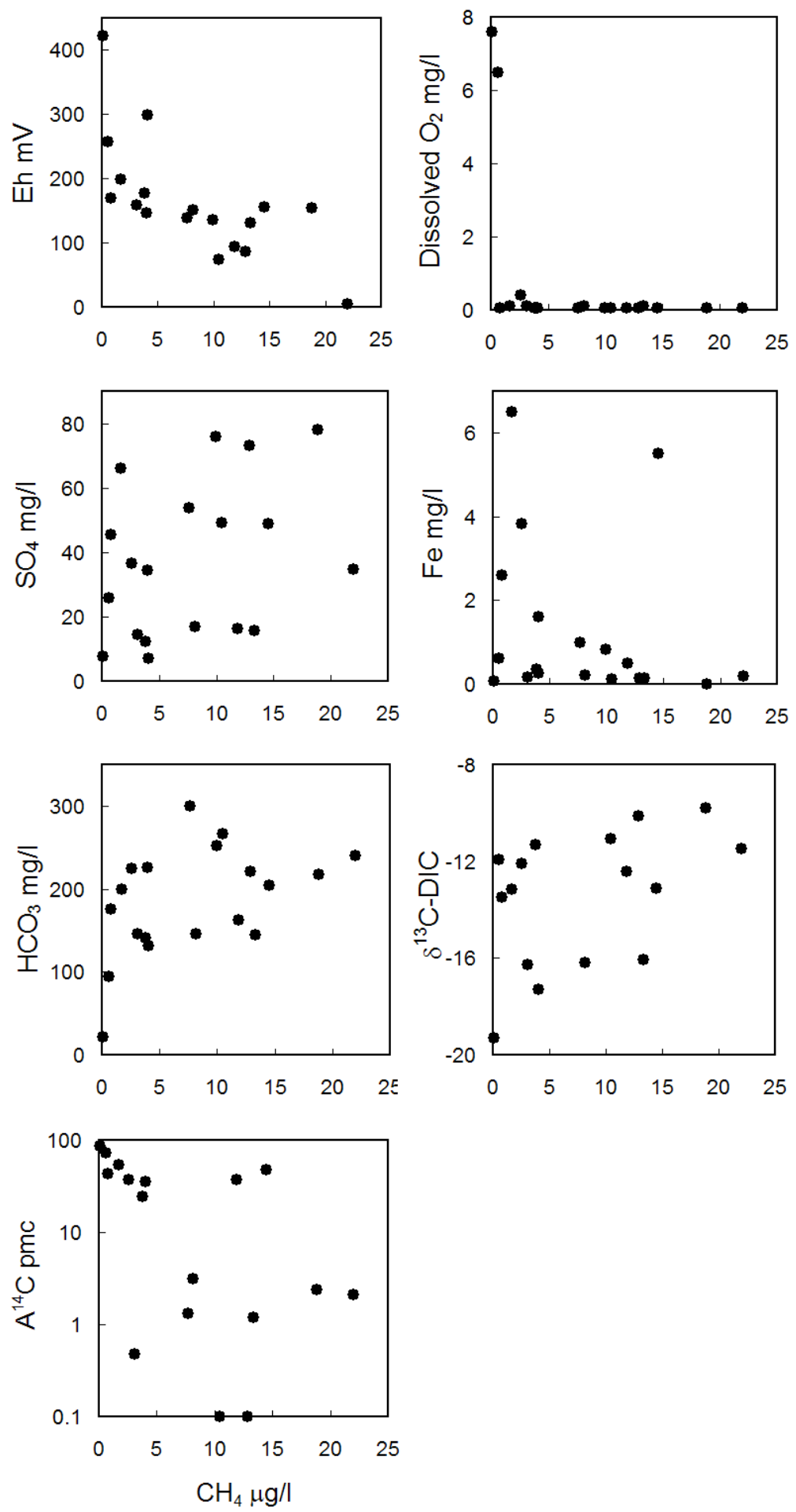

Figure 6 


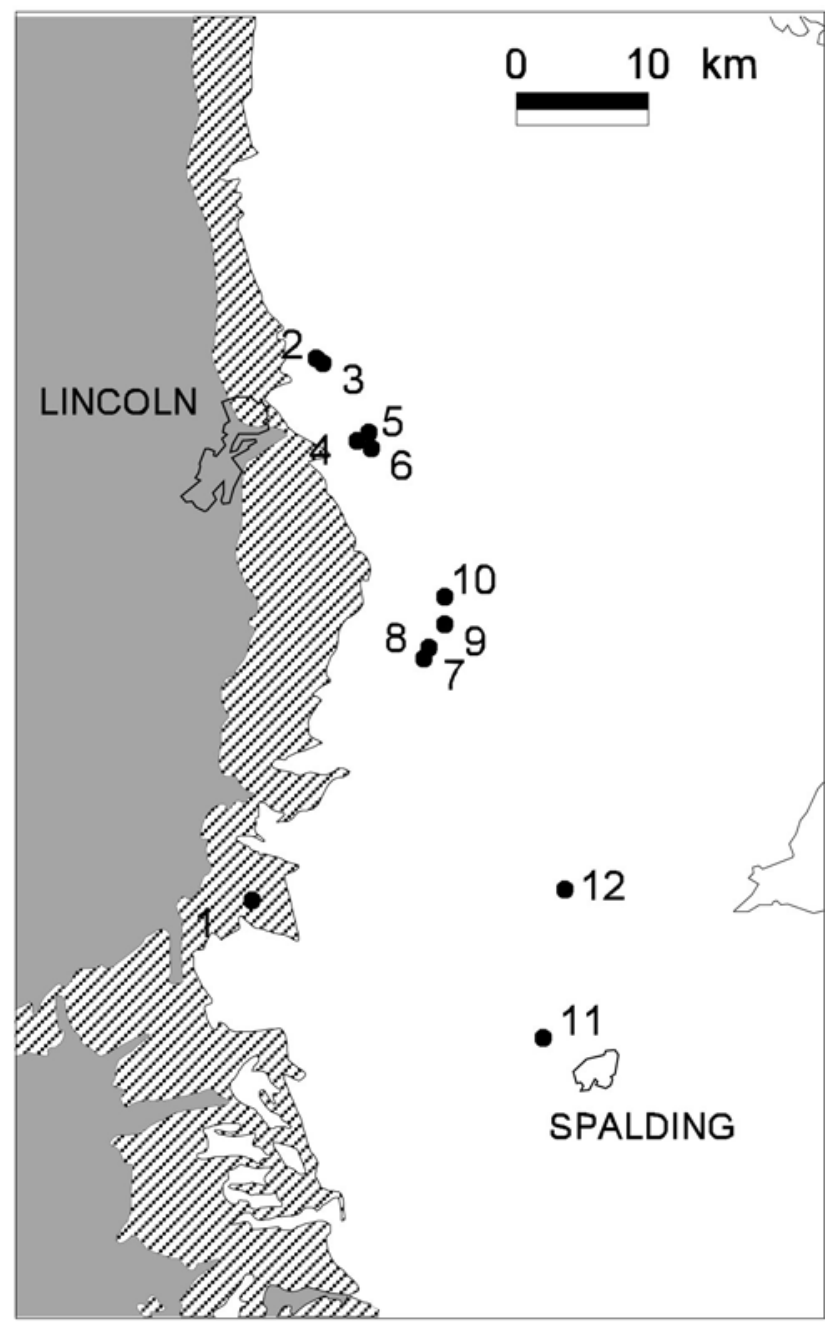

- Sampling sites

Overlying formations Lincolnshire Limestone Underlying formations

Figure 7 


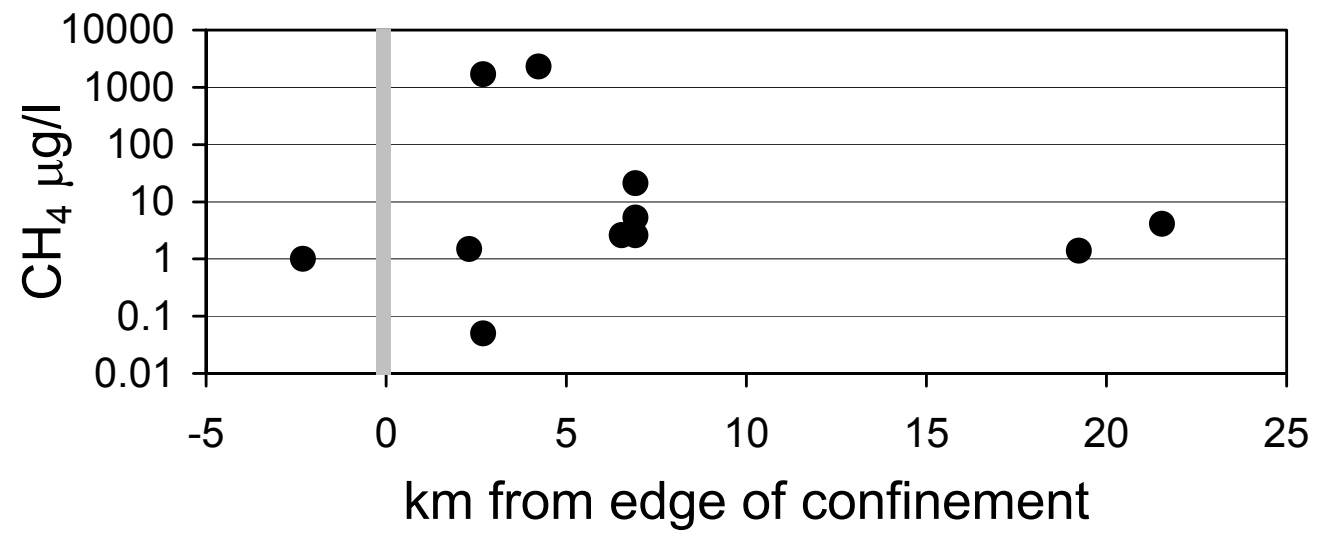

Figure 8 

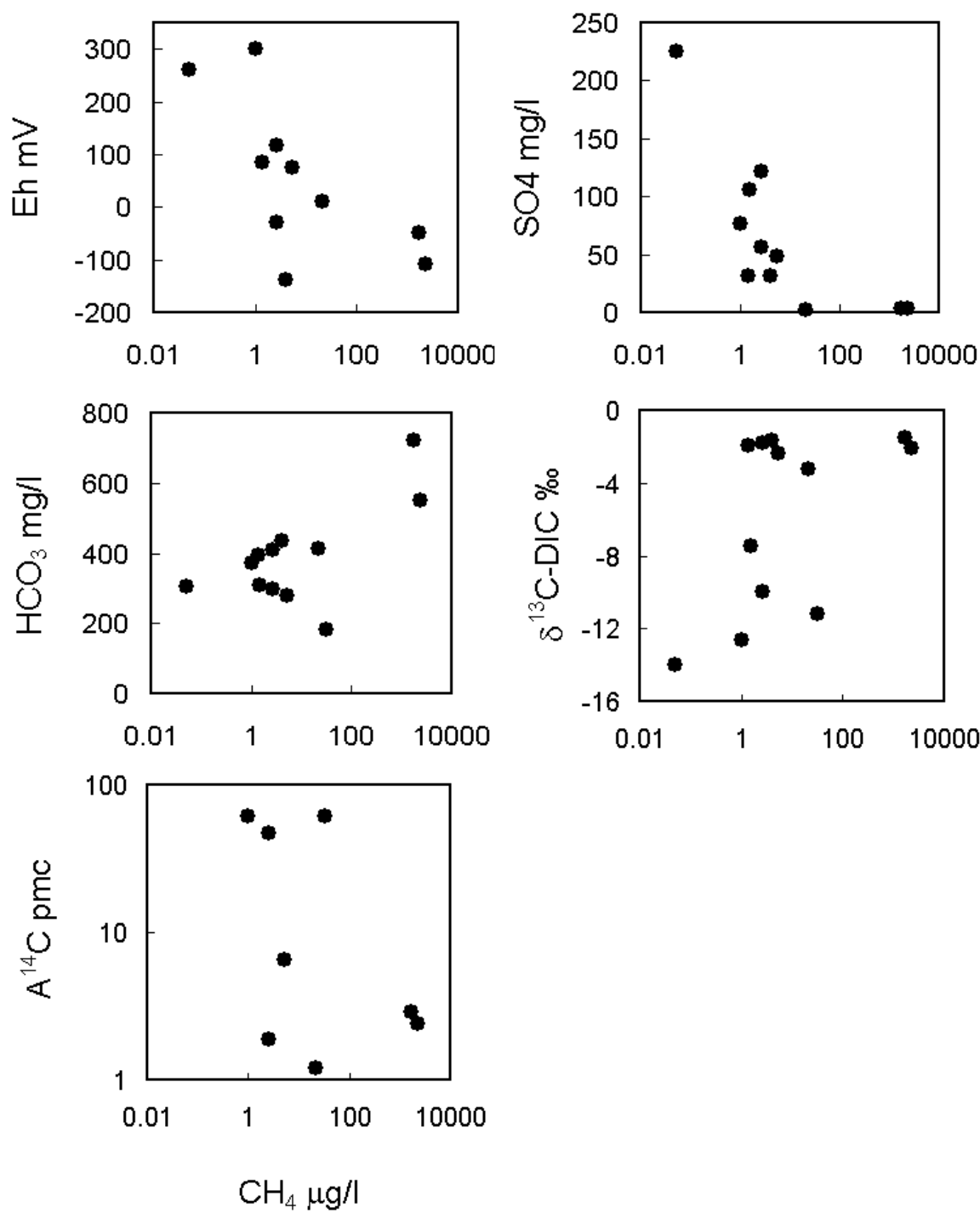

Figure 9 


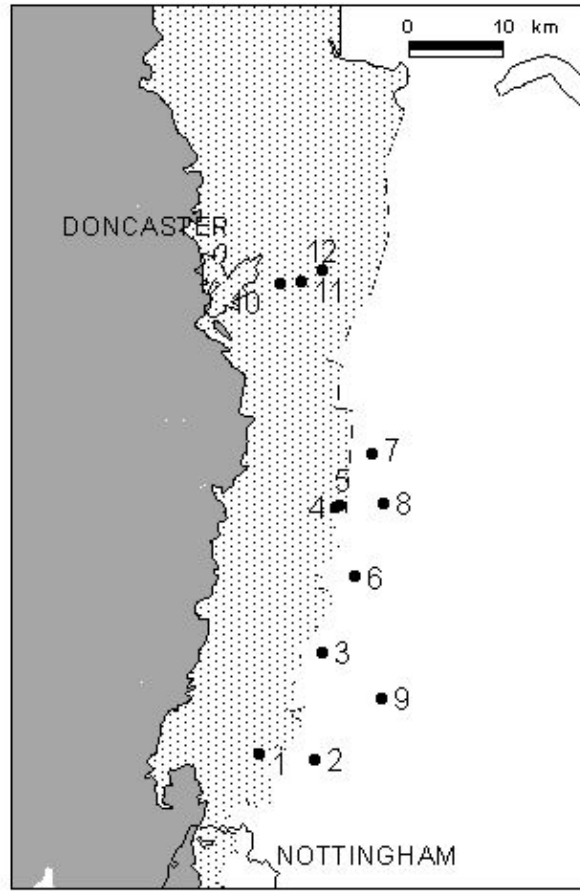

- Borehole locations

Younger Formations

Sherwood Sandstone Group

Older Formations

Figure 10 


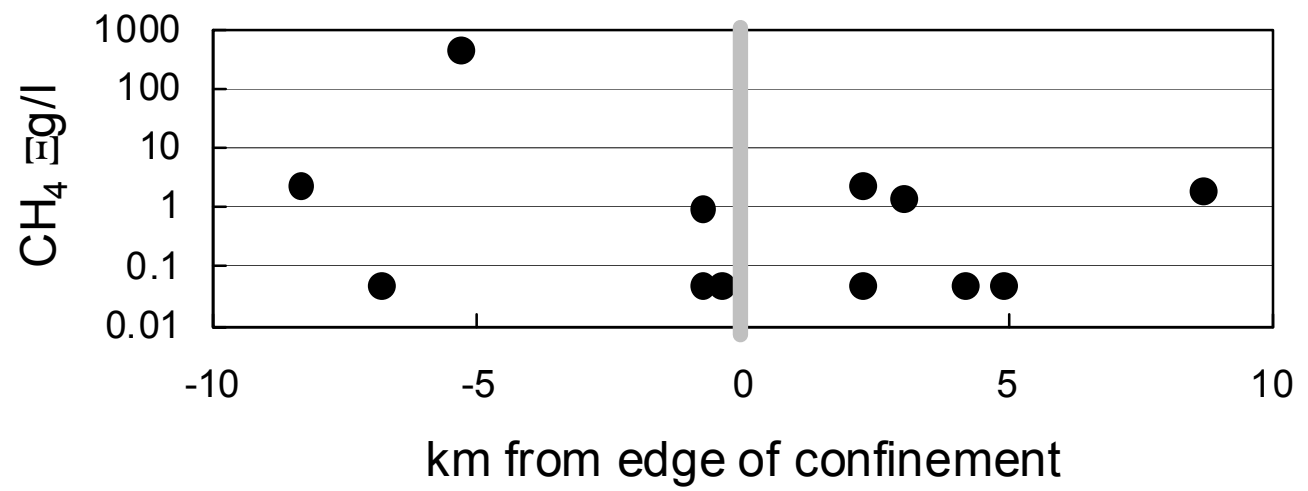

Figure 11 

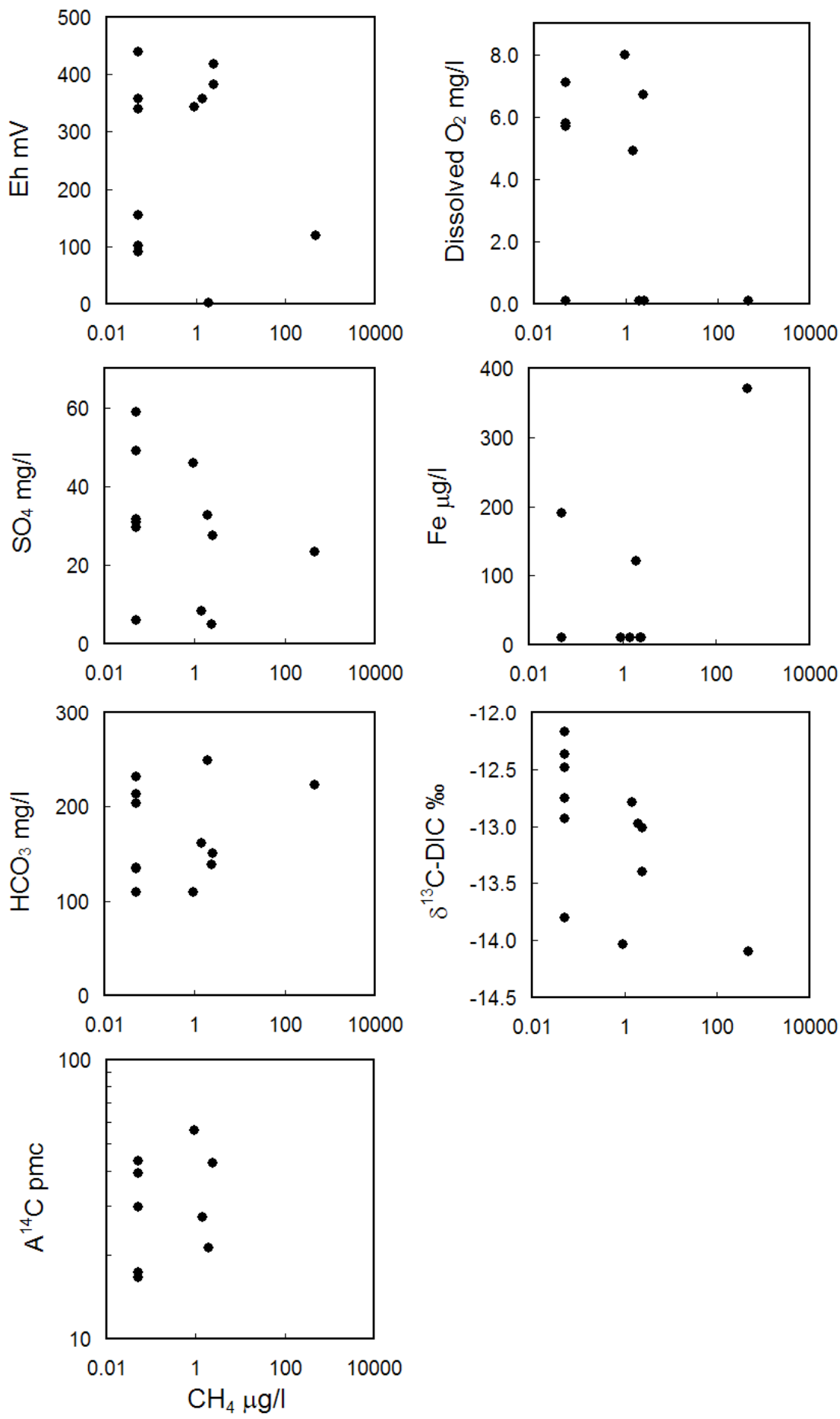

Figure 12 


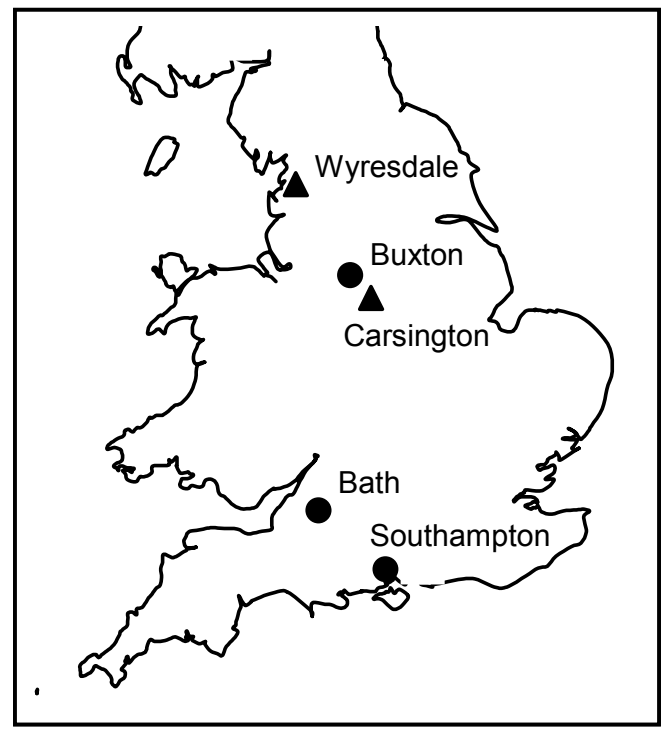

Figure 13 

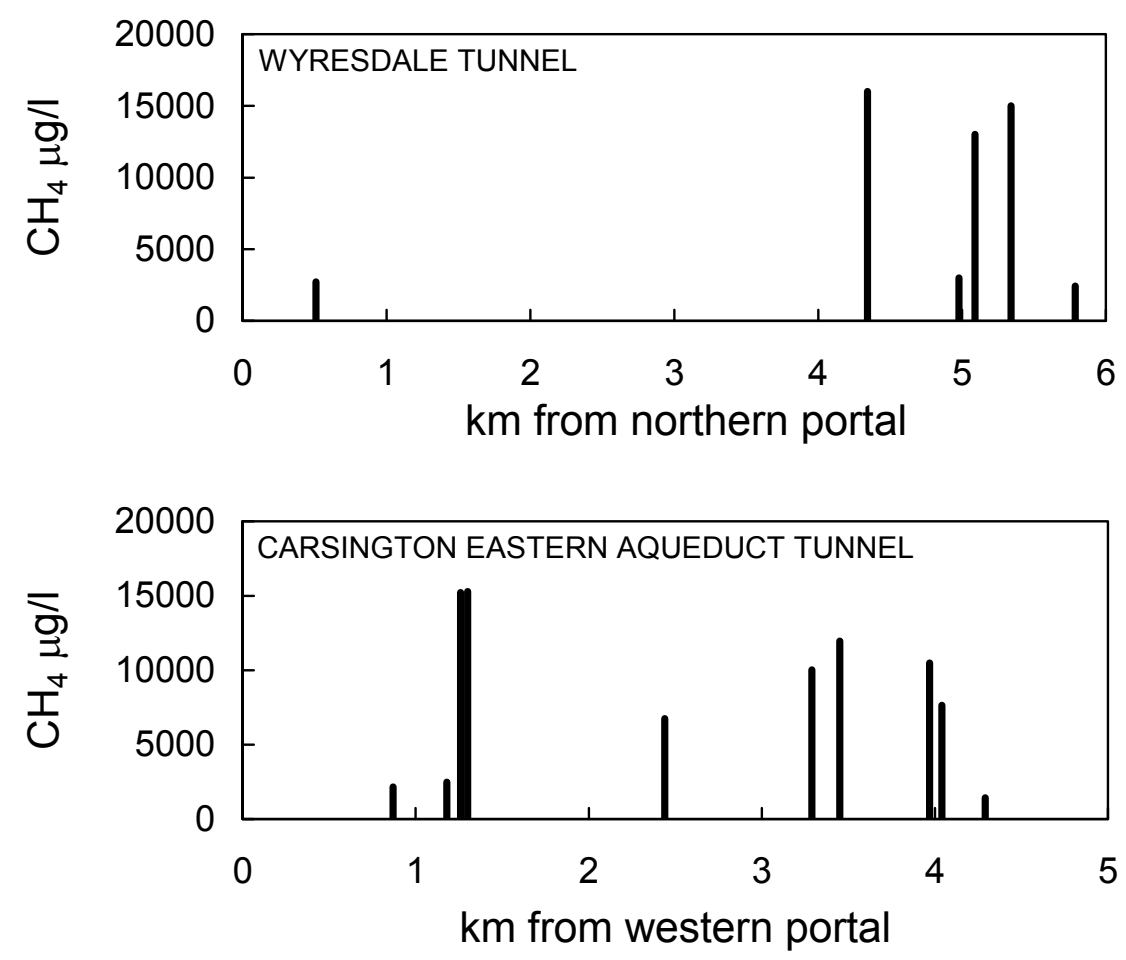

Figure 14 

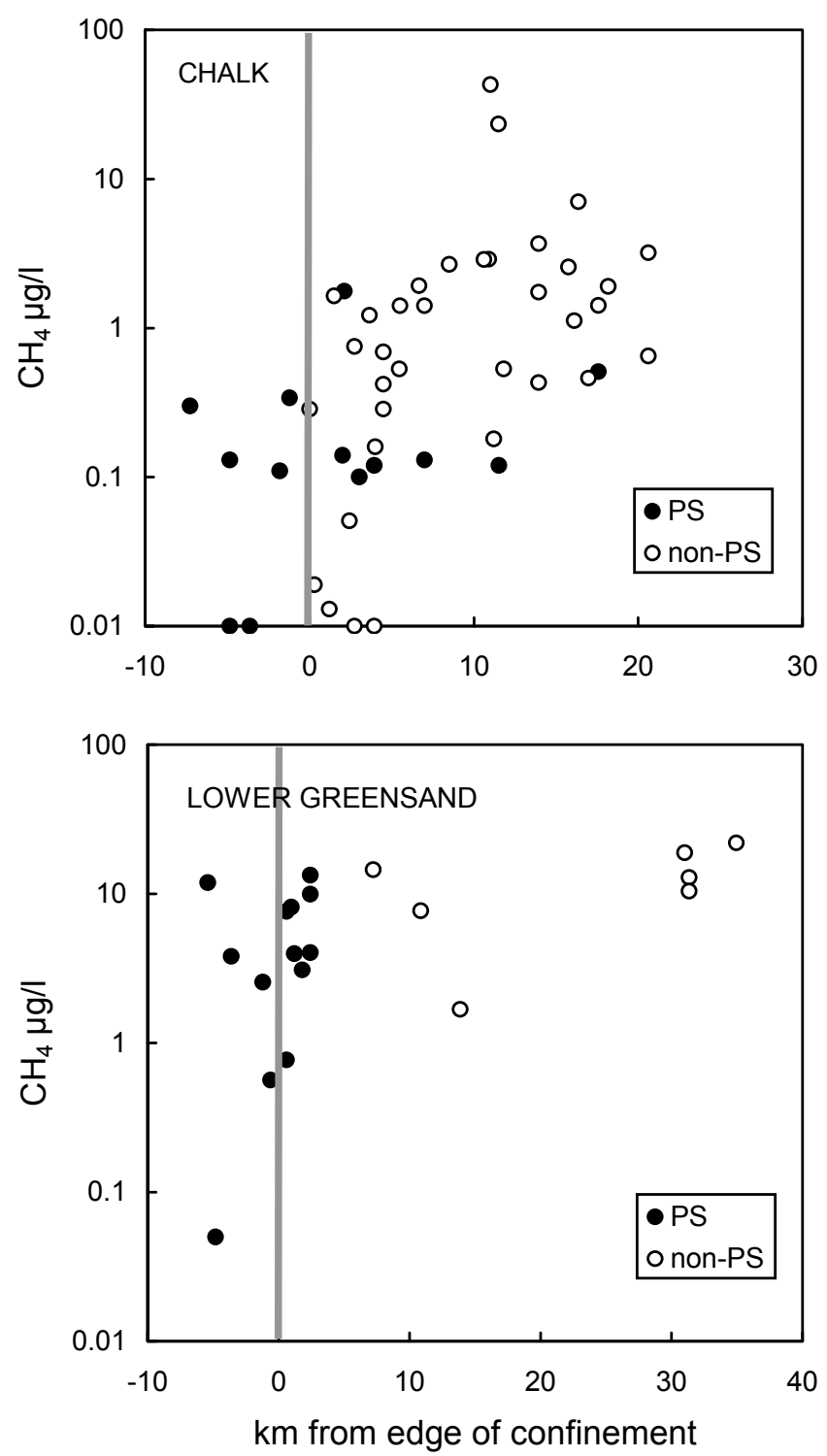

Figure 15 


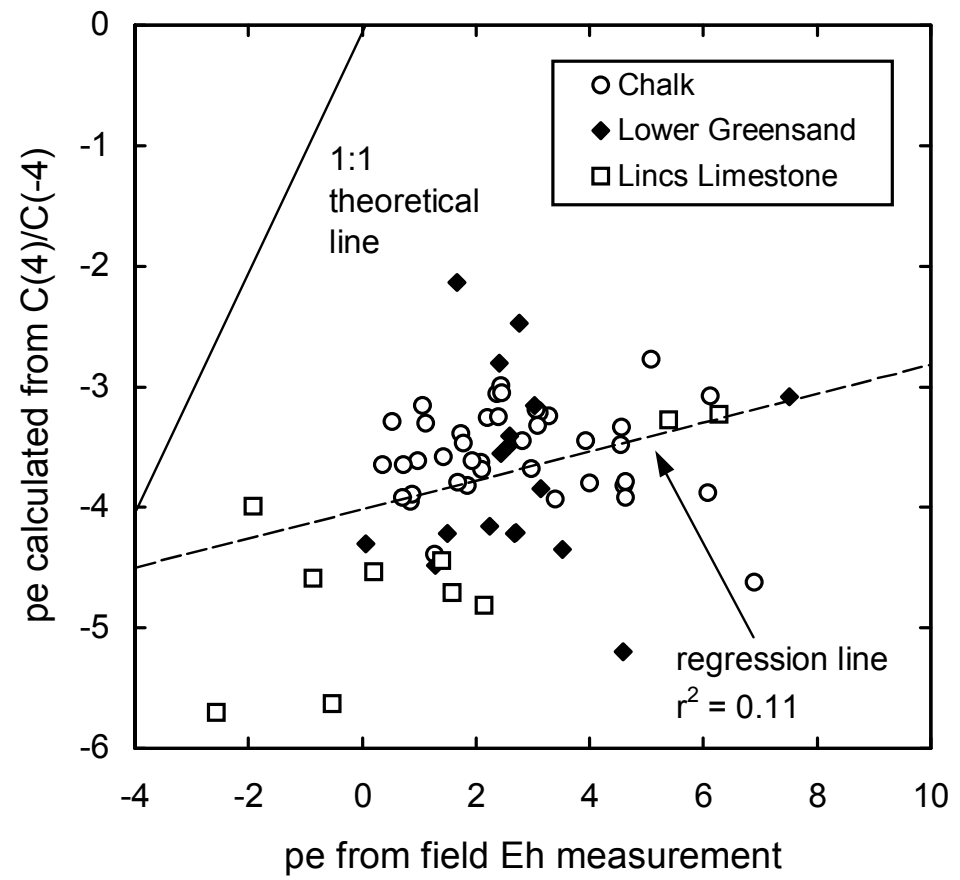

Figure 16 Plot of pe values calculated from the redox couple $\mathrm{C}(4) / \mathrm{C}(-4)$ versus pe derived from field Eh measurements for samples from the Chalk, Lower Greensand and Lincolnshire Limestone aquifers, indicating the sizeable departure from thermodynamic equilibrium for dissolved $\mathrm{CH}_{4}$. 